\title{
The ultrastructure of book lung development in the bark scorpion Centruroides gracilis (Scorpiones: Buthidae)
}

\author{
Roger D Farley
}

\begin{abstract}
Background: Near the end of the nineteenth century the hypothesis was presented for the homology of book lungs in arachnids and book gills in the horseshoe crab. Early studies with the light microscope showed that book gill lamellae are formed by outgrowth and possibly some invagination (infolding) of hypodermis (epithelium) from the posterior surface of opisthosomal limb buds. Scorpion book lungs are formed near the bilateral sites of earlier limb buds. Hypodermal invaginations in the ventral opisthosoma result in spiracles and sac-like cavities (atria). In early histological sections of embryo book lungs, widening of the atrial entrance of some lamellae (air channels, air sacs, saccules) was interpreted as an indication of invagination as hypothesized for book gill lamellae. The hypodermal infolding was thought to produce the many rows of lamellar precursor cells anterior to the atrium. The ultrastructure of scorpion book lung development is compared herein with earlier investigations of book gill formation.

Results: In scorpion embryos, there is ingression (inward migration) of atrial hypodermal cells rather than invagination or infolding of the atrial hypodermal layer. The ingressing cells proliferate and align in rows anterior to the atrium. Their apical-basal polarity results in primordial air channels among double rows of cells. The cuticular walls of the air channels are produced by secretion from the apical surfaces of the aligned cells. Since the precursor cells are in rows, their secreted product is also in rows (i.e., primordial air channels, saccules). For each double row of cells, their opposed basal surfaces are gradually separated by a hemolymph channel of increasing width.

Conclusions: The results from this and earlier studies show there are differences and similarities in the formation of book lung and book gill lamellae. The homology hypothesis for these respiratory organs is thus supported or not supported depending on which developmental features are emphasized. For both organs, when the epithelial cells are in position, their apical-basal polarity results in alternate page-like channels of hemolymph and air or water with outward directed hemolymph saccules for book gills and inward directed air saccules for book lungs.
\end{abstract}

\section{Background}

At the end of the ninteenth century and in the early twentieth century numerous papers were published comparing the development of book gills in the horseshoe crab with the development of book lungs in arachnids, especially spiders. As reviewed by Farley [1], this work was done with the hypothesis that these respiratory structures are homologous, e.g., the internal book lungs in the opisthosoma were derived by insinking of

Correspondence: roger.farley@ucr.edu

Department of Biology, University of California, Riverside, California, 92521, USA

\section{Biomed Central}

the anlage that had previously resulted in external book gills of an aquatic ancestor. There have been diagrams and much discussion about how an ancient ancestor with lamellate gills like extant horseshoe crabs could have given rise to arachnid book lungs [2-12]. Recent investigations of horseshoe crab, scorpion and spider embryos report similar patterns of gene expression at the bilateral opisthosomal sites where book gills or book lungs eventually form [13-17].

In early studies with the light microscope and histological sections, the air sacs (air channels, lamellae, saccules) of developing spider and scorpion book lungs 
were suggested to be infoldings of the hypodermis from the spiracular invagination (primordial atrium) posterior to opisthosomal limb buds. This process was thought to be similar to the small amount of invagination that may occur along with outgrowth folds for book gill development at the posterior surface of branchial appendages in horseshoe crabs [2-10,18-22]. Slight widening of the air sac entrance at the atrial wall was interpreted as indications of hypodermal infolding. The presumed infoldings were thought to result in the parallel rows of lamellar precursor cells anterior to the atrium. In the spider species they examined, Montgomery [23] and Janeck [24] reported that the initial widenings of the air sac entrance are transitory, and the air sacs are formed from aligned cells in a cluster derived from the hypodermis.

More recently for the spider Cupiennius salei [25], the segment polarity gene engrailed-1 is reported to be expressed as five stripes at the site where lamellae originate posterior to the second opisthosomal limb buds. The primordial site is invaginated and covered ventrally by the posterior folding and flattening of the preceding limb bud, as reported in earlier histological studies $[8,23]$. Also in C. salei, the developmental gene $p d m /$ nubbin is expressed in a striped pattern possibly related to lamellar formation [15].

In his diagram of histological sections of scorpion embryos, Brauer [19] showed some small folds in the atrial wall. This was considered as evidence of hypodermal invagination like that proposed for book gills $[17,22,26]$ although the presumptive folds were not actually shown to be related to the formation of book lung lamellae.

As pointed out earlier [1], lamellate respiratory organs are important for our understanding of evolutionary history and taxonomic relationships, but modern procedures are needed for a more detailed comparison of cell activity during book gill and book lung development. The main objective herein is to use transmission electron microscopy (TEM) to examine cell ultrastructure during formation of scorpion book lungs. The results can then be used where relevant and helpful for evolutionary hypotheses and further comparative studies.

The scanning electron microscope (SEM) was used in recent developmental investigations of the respiratory organs in the scorpion [27] and horseshoe crab [1]; the present investigation is a continuation of that effort. The SEM study of book lung development in scorpions [27] provides an overview of the process, but the SEM is limited in the resolution of cell detail. Also, tissue preparation requires dissection and/or fracturing to expose components for viewing. This has potential for cell damage and/or loss, with emphasis on the surface features of the tissue or organ. In the present study, whole book lungs were removed, and sections were cut at successive stages of development in embryos and first and second instars.

Book lung formation in scorpions is a slow and gradual process [27]. It begins in the embryo with the appearance of a spiracle and a sac-like invagination (primordial atrium) just inside the spiracle. Lamellar development continues through birth and the first molt that occurs 1-2 weeks after the newborn first instars (pronymphs) climb up on the mother's back. The book lung gradually becomes a functional respiratory organ with about 50 lamellae in the active and foraging second instar. The book lung cuticle is replaced in subsequent molts [28], and lamellae are increased in size and number so there are more than 150 in the adult. The earlier [27] and present investigations show a complex developmental process of cell proliferation, migration, alignment and secretion of cuticular materials. The result is a stable and highly ordered series of page-like air and hemolymph channels.

Information about scorpion anatomy and morphology and the general organization of scorpion book lungs and horseshoe crab book gills is provided in earlier publications [1,29-31].

\section{Methods}

Gravid females of Centruroides gracilis [32] were purchased from a supplier (Strictly Reptiles, Hollywood, FL). Information about taxonomy and life history is provided by Francke and Jones [33], Sissom and Lourenço [34], Ades [35] and Fet et al. [36]. For taxonomy of spider species mentioned herein, the new Platnick catalog [37] is available on-line.

Maintenance of animals and the dissection and preparation of tissues for SEM were done as described by Farley [27]. For TEM, microscissors and forceps were used to remove the spiracle, booklungs and attached soft cuticle from embryos, while only the spiracle and booklungs were removed from the first and second instars. Tissues were fixed $6-12$ hours $\left(23-25^{\circ} \mathrm{C}\right)$ in $2.5 \%$ glutaraldehyde in $0.1 \mathrm{M}$ cacodylate buffer. The tissues were washed in $0.1 \mathrm{M}$ buffer and postfixed (1-2 days) in $1 \% \mathrm{OsO}_{4}$ in $0.1 \mathrm{M}$ cacodylate buffer. Tissues were dehydrated in a graded series of ethanol and embedded in Spurr's [38] plastic. Ultrathin sections were cut on a RMC MT-X microtome (Boeckeler Instruments) and collected on grids pretreated with formvar or parlodion. The sections were stained with alcoholic uranyl acetate and lead citrate [39] and examined at $120 \mathrm{kv}$ with a FEI Tecnai 12 (formerly Philips) electron microscope. Semi-thin sections were stained with warming and a mixture of $0.5 \mathrm{~g}$ toluidine blue, $0.5 \mathrm{~g}$ sodium borate and $20 \mathrm{ml}$ of methyl alcohol in $200 \mathrm{ml} \mathrm{H} \mathrm{H}_{2} \mathrm{O}$. 


\section{Results}

Shown herein are typical examples of lamellar formation in successive developmental stages, but early book lung development is a continuum rather than a series of discrete steps related to the age of the individual. Within each scorpion there is a longitudinal gradation in the rate at which the book lungs develop, with the posteriormost pair (opisthosomal segment 7) the most advanced. In the early embryo, the limb buds of the third mesosomal segment gradually develop the features of pectines that temporarily overlap on the ventral surface of segment four [27,40-42]. The book lungs of this segment begin developing later than all those more posterior as the pectines separate from the ventral surface of the segment [27]. Additionally, within each book lung there is a gradation in the formation of lamellae; the most advanced lamellae are in the medial and central part of the book lung while the lateral edge has lamellae forming from newly aligned cells. Little or none of the book lung cuticle is shed as exuvium in the first molt [27], so most of the initial lamellae continue differentiation in the second instar.

\section{Epithelial proliferation, ingression and alignment}

As reported earlier [27,40-43], the limb buds on opisthosomal segments 4-7 disappear well before spiracles appear on the ventral surface. The entire segment 1 disappears while the limb buds on segment 2 become the genital operculum and those on segment 3 become the pectines. The spiracles are initially near the posterior margin of segments 4-7 (Figure 1). Also at the posterior segment margin, small flap-like primordial sternites appear about the same time as the spiracles (Figure 1). In later stages of the embryo and beyond, the sternites increase in size, and the spiracles are seen at a more anterior location, apparently as a result of differential growth of the tissues [27].

The spiracles open into the atrium, a sac-like cavity formed by invagination of the external hypodermis at the spiracle site (Figures 2A, B and 3). The invaginated hypodermis consists of a layer of epithelial cells with apical-basal polarity, i.e., a thin cuticle at their apical surface and a basement membrane at their basal surface (Figure 2A, B). From this invaginated epithelium, the cells appear to proliferate and migrate inward (ingress) and arrange themselves in rows anterior to the atrium (Figures 2A, B and 3). As evident in the following figures, this alignment of the book lung precursor cells is the structural foundation for the regular pattern of page-like lamellae.

Figures 2A, B and 3 are book lung examples with increasing differentiation and development of the air sacs. As shown in these figures, the cuticle wall of the atrium becomes thinner where lamellae are forming, and the basement membrane is disrupted where cells are migrating inward. In Figure 3, an epithelial layer and basement membrane are no longer evident since the epithelial cells have apparently dispersed inward. The air sacs in Figure 3 are more prominent than those in Figure $2 \mathrm{~A}, \mathrm{~B}$, and some air sacs in Figure 3 are especially wide and dense as a result of their granular contents (described in more detail below).

Figures 2A, B and 3 have regions where the precursor cells are not yet organized into double rows separated by developing air sacs. Some cells at this stage are shown in the electron micrograph of Figure 4. These cells are irregular in shape and show no indication of the apical-basal polarity that is prominent in subsequent stages (Figures 5, 6, 7, 8, 9, 10, 11). The cells have many fine particles, probably ribosomes and granules; the latter may eventually become part of the cuticular walls of the air sacs (Figures 12, 13, 14).

\section{Apical-basal polarity, secretion}

Beginning at the atrium, the aligned precursor cells soon begin to show indications of the polarity that is common among epithelial cells, i.e., secretion at the apical surface while the basal surface is in contact with hemolymph where nutrient transport can occur [44]. This difference in activity between the apical and basal surfaces of the aligned cells results in a regular pattern of developing air sacs among double rows of cells (Figures 2A, $B$ and $3,6,7,8,9,10,11)$. Since the precursor cells are in parallel rows, their secreted product (i.e., primordial air sacs) are also in parallel rows. Air sacs separated by double rows of cells were observed in early light microscopic studies of book lung development in spider embryos $[8,9,18,20,21,23,24,45]$. Some of these authors also observed slight widening at the atrial entrance of a few air sacs. As described in Background, this widening was hypothesized to be evidence of hypodermal invagination (infolding) as the basis for the cell alignment anterior to the atrium.

In this scorpion investigation, some widening of the air sac entrance was seen for some more advanced air sacs (Figures 2B, 3), but not in the initial stages of air sac formation (Figures 2A, 6, 7) as would be expected if infolding of the atrial wall hypodermis had resulted in the cell alignment for the air sacs. As noted in Background, some presumptive folds in the atrial wall were interpreted as evidence for atrial wall invagination in the formation of book lung lamellae in scorpion embryos, although a relationship between folds and lamellae was not shown $[19,22]$. The structures diagramed as folds may have been small widenings of the air sac entrance as observed in the book lungs of spider embryos.

In the initial stages of air sac formation, a thin line of osmiophilic material suggests merocrine secretion from 


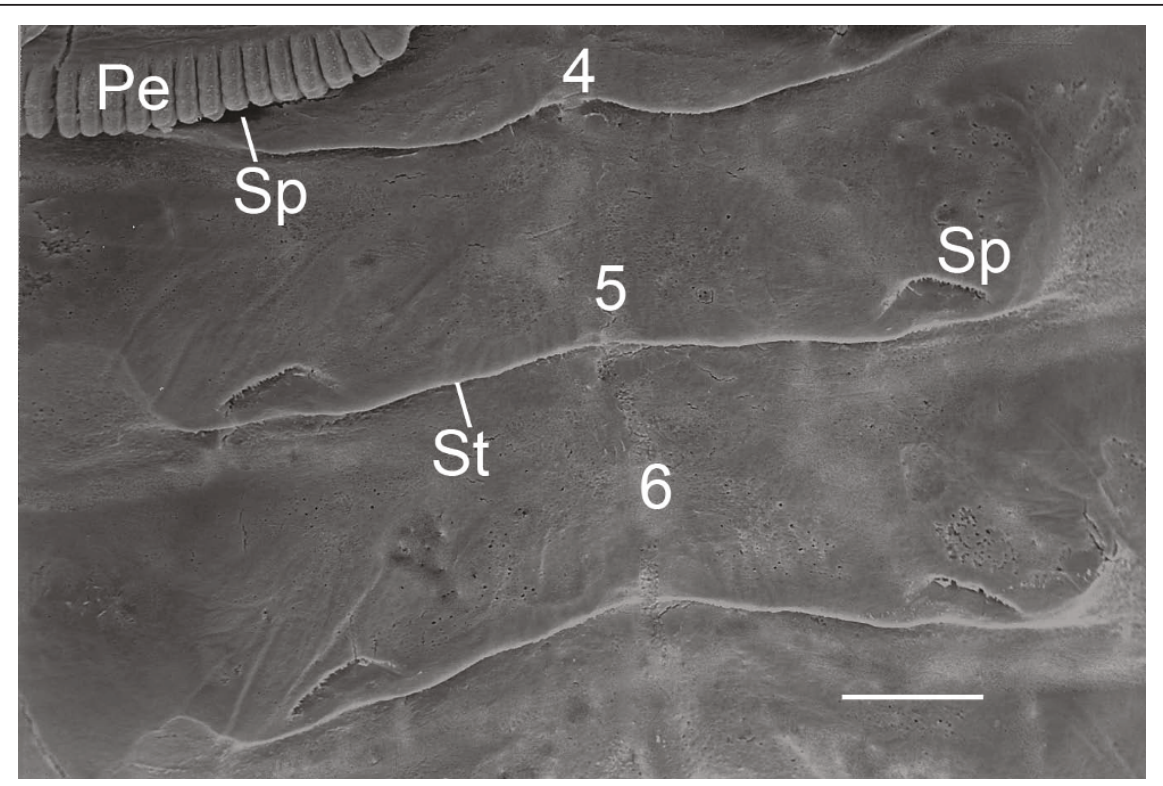

Figure 1 Ventral view of embryo opisthosoma with spiracles (Sp) and small flap-like sternites (St) starting to form. Centruroides gracilis, supine. SEM. The spiracles evident here are near the posterior margin of segments 4, 5 and 6 . The spiracles on segment 4 are only partially visible because the pectines $(\mathrm{Pe})$ from segment 3 still overlap on the ventral surface of segment 4 . The spiracles are open with no closing mechanism until after the first molt (second instar). Scale, $200 \mu \mathrm{m}$.

the apical surface of the aligned cells (Figures 5, 6), and the release of apical portions (apocrine secretion) of these cells (Figures 6, 7, 8) forms an elongate channel of cell fragments (Figures 8, 9, 10, 11). In later stages, entire cells are disrupted (holocrine secretion, Figure 12), increasing space for hemolymph at the base of the remaining cells and contributing components to the cuticular walls of the air channel (Figures 12, 13).

Figures 6, 7 and 8 show early stages of cell fragmentation from the apical surface of the aligned cells. This process starts near the atrium, and continues anteriorly among the cell rows. It is sometimes difficult to recognize the location of the future air sacs and hemolymph channels among the disrupted cell components, and there is no widening of the air sac entrance at the atrial wall where the cell fragmentation is occurring (Figures $2 \mathrm{~A}, 6,7)$. The cell fragments are surrounded by a plasma membrane, and the fragments contain vesicles and granules (Figures 6, 7, 8) as in the cells of origin. In addition, the fragments are in a narrow and elongate lumen that is somewhat dense (Figures $8,9,10,11$ ) as though a fluid is present with material secreted from the apical surface of the adjacent cells.

\section{Fusion of cell fragments, cuticle formation}

Within the primordial air channels, the cell fragments appear to fuse together to form more elongate strands of membrane-bound cytoplasm (Figures 8, 9, 10, 11). The fragments and secretions from the aligned cells apparently contain enzymes and molecular components for cuticle since electron-opaque particles are formed within the cell fragments. The dense particles appear especially at the outer membrane of the cell fragments (Figures 8, 9, 10, 11) where they coalesce in the formation of a continuous cuticular wall (Figures 9, 10). There are regions of increased density and thickness of the outer covering of the conjoined cell fragments (Figures 9, 10). Thin lines of electron-opaque material (presumptive merocrine secretion) can also be seen at the apical surface of the cells adjacent to the developing air sacs (Figures 8, 9, 10). The initial cuticular wall of the developing air sac is apparently produced by formation and coalescence of dense, electron-opaque material within the cell fragments and secreted at the apical surface of the precursor cells.

In these early stages of book lung development, cells with large $(\sim 1 \mu \mathrm{m}$ dia.) electron-opaque granules are sometimes seen among the other precursor cells. Examples were seen where these cells release fragments with large granules that become part of the developing air sac. Once inside the primordial air sac, these granules make the air sac somewhat wider and more dense than the other air sacs without these granules (Figures 3, 11). The center of the granules becomes lucent (Figure 11) as though the material is removed and/or migrating toward the periphery of the granule where fusion of the fragments and coalescence of the dense material can result in a continuous cuticular wall. This process may be similar to the coalescence of small particles at the 

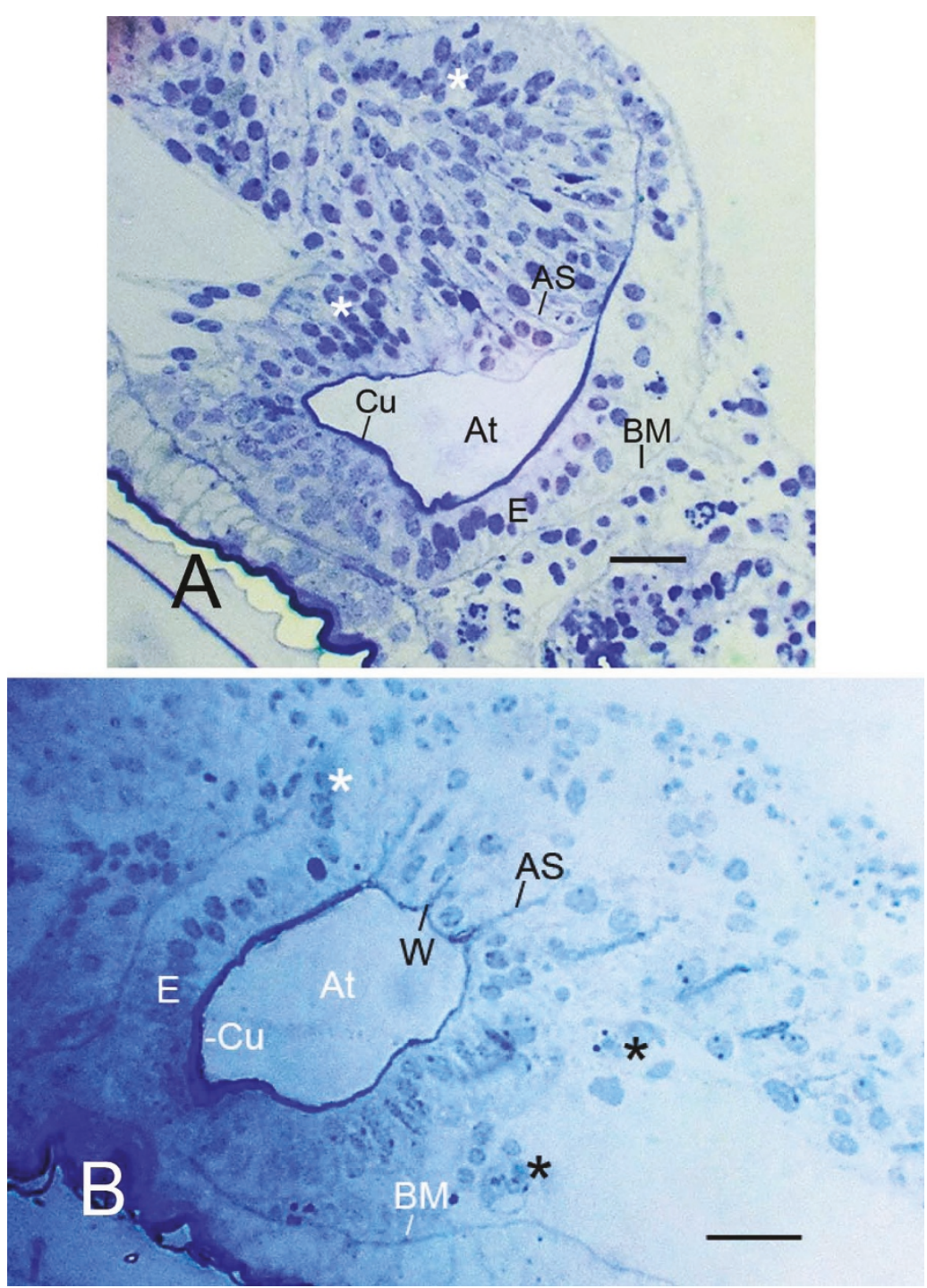

Figure 2 Proliferation and migration of precursor book lung cells from the invaginated epithelium (E) of the atrium (At). Light micrographs $(L M)$, ventral views, semi-thin sections. Centruroides gracilis. A. Newborn first instar. The air sacs (AS) in this book lung are at an early stage and barely discernible. Little or no widening is evident at the atrial origin of the air sacs. The cuticular wall (Cu) of the atrium is absent or very thin at the sites where air sacs are forming. The epithelial cells of the atrial wall are in a distinct layer where lamellae are not being formed; a basement membrane (BM) is present at the basal surface of these cells. The cells in the epithelial layer toward the left in the photo are more numerous as though proliferating near the site where air sacs are forming. On either side of the region of developing air sacs, the basement membrane is absent or disrupted and the precursor cells appear to be migrating inward (asterisks). B. Embryo book lung with some air sacs more advanced than those in Figure 2A. Inside the wall of the atrium, epithelial cells (E) of the hypodermis form a layer with a basement membrane (BM) at their basal surface. The cuticular wall (Cu) of the atrium is much thinner at the site where air sacs are forming. The primordial air sacs (AS) separate aligned precursor cells into double rows. Some cells (asterisks), not yet aligned into rows, appear to be dispersing inward from the atrial epithelium, and at these sites the basement membrane is disrupted or absent. Some widening $(\mathrm{W})$ of the air sac entrance is evident at the atrial origin of two air sacs. In the lateral region (right) of the book lung, the developing air sacs are barely evident among cells not yet aligned. Scales, $20 \mu \mathrm{m}$.

periphery of cell fragments in the primordial air sacs (Figures 8, 9, 10, 11).

As shown in Figures 8, 9, 10 and 11, the outer wall of the air sac fragments gradually becomes dense and thicker, so that the former cell fragments enclosed in plasma membrane are now cuticle-enclosed air sac components, labeled as $\mathrm{CuC}$ in Figures 12 and 13. The cell fragments and more advanced cuticle-enclosed components appear to fuse and form a continuous, elongate structure (Figures 9, 10, 11, 12). Some cells adjacent to the air sacs are disrupted as they release granules and vesicles that appear to increase the thickness of the 


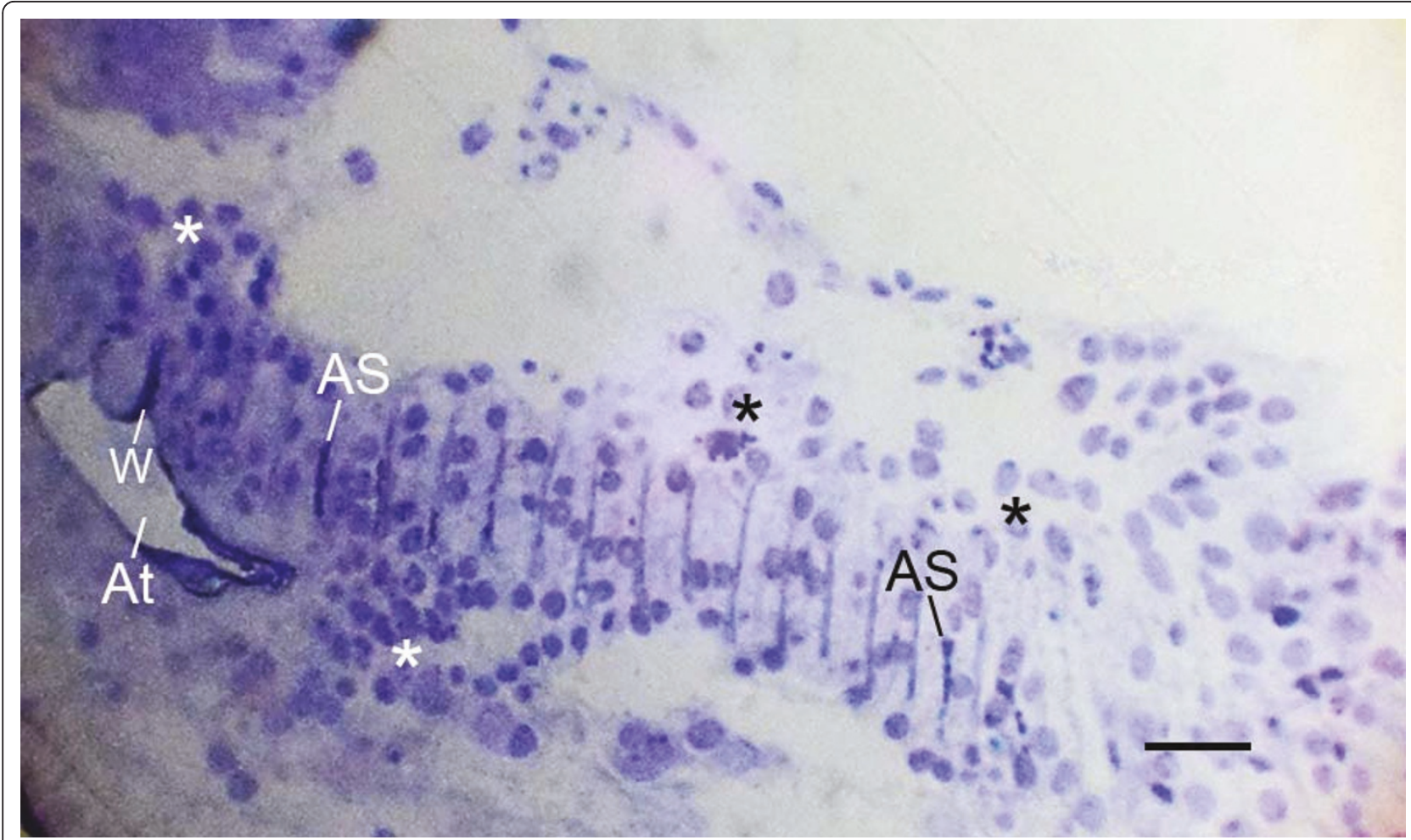

Figure 3 Some air sacs (AS) with dense and opaque contents in a book lung more advanced than those in Figure $2 A, B$. $L M$, ventral view, semi-thin section. Centruroides gracilis, newborn first instar. The portions of air sacs evident here are more prominent than in Figure $2 A, B$, and some air sacs (AS) are wider and more dense than the others because of the granular contents (see below). The air sacs are formed between double rows of cells. Some widening (W) of the air sac entrance is evident at the atrial origin of two air sacs. The asterisks indicate cells that are not yet aligned into rows or separated by primordial air sacs. Probably as a result of the proliferation and inward migration of cells, the atrium (At) no longer has an epithelial layer with basement membrane (compare with earlier stages in Fig. 2A,B). Scale, $20 \mu \mathrm{m}$.

cuticle walls (Figure 12). The disruption leaves cell debris and additional space for fluid in the primordial hemolymph channels. Granules and vesicles from the deteriorating cells are often seen in contact with the inside and outside of the cuticular walls as though merging with the wall and/or releasing components that become part of the wall (Figures 13, 14). This process of cuticle formation in scorpion embryos was also observed in earlier studies with SEM [27] and TEM [46].

As shown in Figures 2A, B, 3, 4, 5, 6, 7, 8, 9, 10, 11 and 12 , the precursor cells $(\sim 3-8 \mu \mathrm{m}$ wide) are much larger than the early air sacs. The width of the air sacs is determined by the amount and size of the material released from the apical surface of the aligned cells. The latter apparently release similar quantities since each of the resulting channels has a fairly uniform width throughout their length. In these early stages of development, the channel width varies from a dense line $(\sim 0.1 \mu \mathrm{m}$, Figures 5,6$)$ to an elongate row of fragments $1-2 \mu \mathrm{m}$ in width (Figures $8,9,10,11$ ). With the loss of cells and likely exchange of materials across the basal surface of the aligned cells, the examples of hemolymph channels herein increase in width from $0.3 \mu \mathrm{m}$ (Figures $8,9,10,11$ ) to $\sim 6 \mu \mathrm{m}$ (Figures 15, $16,17)$.

\section{Formation of space holders (trabeculae)}

Within the air channel lumen, trabeculae may be formed by fusion of the cuticularized walls of the former cell fragments (Figures 12, 13). Cells attached to the developing cuticle walls of the channel can also extend processes into the lumen of the air sac (Figure 14). These processes often contain granules and vesicles that may become part of the cuticle. Apparently, the cellular processes continue elongation into the lumen, make contact with the opposite wall and become cuticularized. Trabecular formation results in many space holders that help hold the cuticle walls in place and prevent their collapse and blockage of air flow in the narrow and elongate channels. Space holders that connect with both walls of the air channel (bridging trabeculae, cross bridges) is the only type seen in the present investigation of the early stages of book lung development, although numerous other types of space holders are 


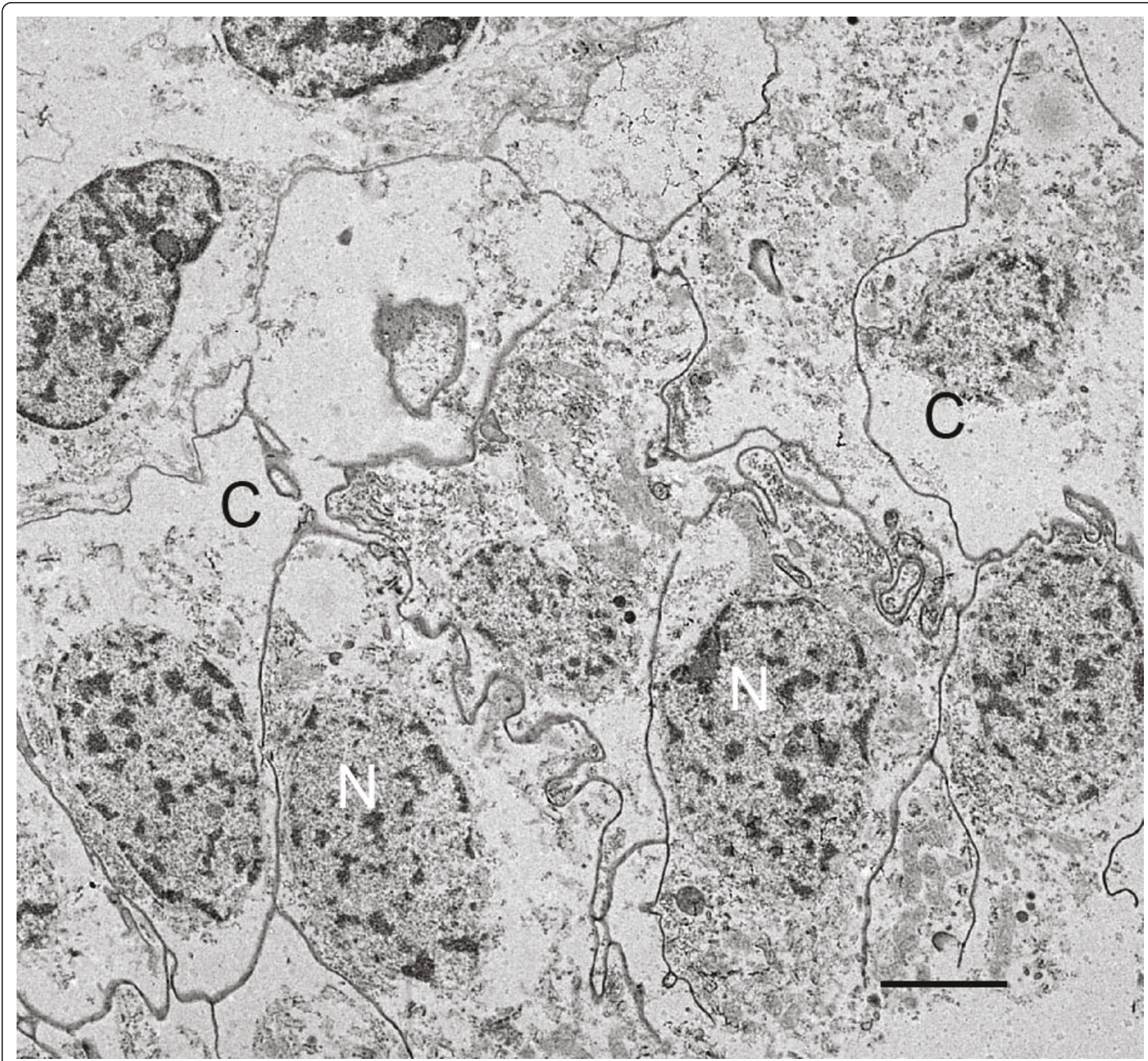

Figure 4 Book lung precursor cells $(\mathbf{C})$ not yet aligned anterior to the atrium. Centruroides gracilis, embryo. TEM. The cells have irregular shape and many small particles, possibly ribosomes and granules. Primordial air sacs, hemolymph channels and apical-basal polarity are not yet evident among these cells. N, nucleus. Scale, $2 \mu \mathrm{m}$.

found in adult scorpions [30]. In this investigation, there are many examples of trabeculae that do not extend all the way to the opposite wall (Figures 14, 15, 16, 17), possibly because the space holder is incomplete or the entire bridging trabecula was not evident in the section.

As shown in Figure 15 (first instar), a regular pattern of lamellae results from the somewhat disorderly process of cell secretion and disruption described above. Trabeculae that partially and completely span the width of the air channels are abundant in the example of Figure 15. The air sacs contain little cell debris and are nearly open for passage of air except for the slender trabeculae. A thin layer of epithelial cells is attached to the hemolymph surface of the air sacs. These cells form a hypodermis in position to produce page-like replacement cuticle in later molts.

Some of the first instars examined in this investigation were thought to be close to their first molt, but in the sections there was no indication that lamellar epithelial cells were secreting new cuticle walls as preparation for the first molt. As shown in an example of first-molt exuvium [27], some replacement of lamellar cuticle may be needed only in the distal parts of the posteriormost booklungs. 


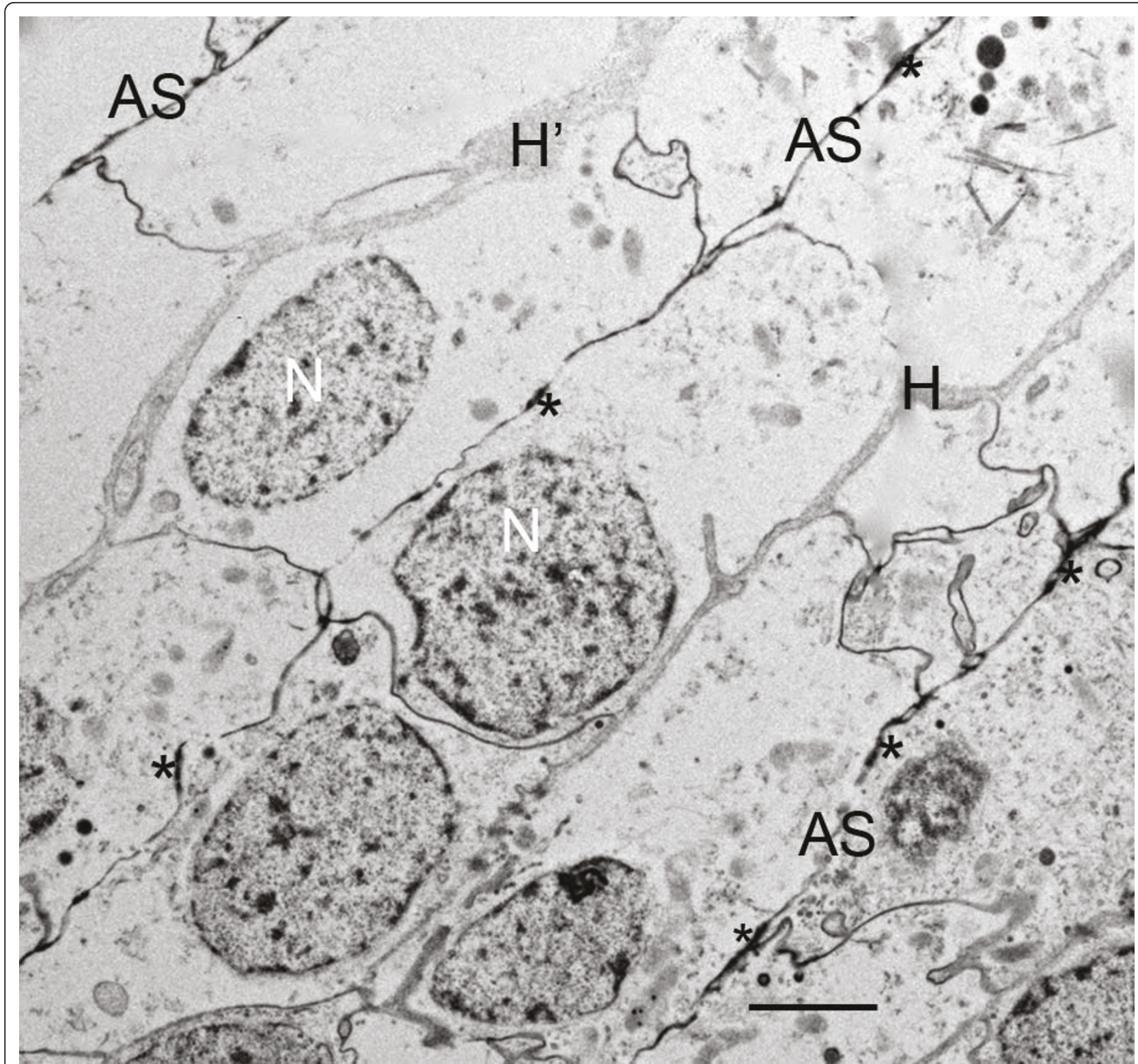

Figure 5 Early stage in the development of air sacs (AS) among parallel, double rows of book lung precursor cells anterior to the atrium. First instar, Centruroides gracilis. TEM. At this site somewhat inward from the atrium, the air sac channels begin with osmiophilic material (asterisks) that is apparently the result of merocrine secretion and/or enzyme action at the apical surface of the aligned cells. The basal surface of these cells is in contact with the primordial hemolymph channels $(\mathrm{H})$, about $0.2 \mu \mathrm{m}$ in width; one region $\left(\mathrm{H}^{\prime}\right)$ appears to be widening $(\sim 1.0 \mu \mathrm{m})$. Irregular wider regions like this gradually become more common. $\mathrm{N}$, nucleus. Scale, $2 \mu \mathrm{m}$.

\section{Hemolymph channels}

Figure 16 shows an example of book lung lamellae from a second instar within 24 hours after the first molt on the mother's back. The lamellae appear to be at a similar stage of development as those in the advanced first instar of Figure 15. Some cells attached to the hemolymph surface of the air sac wall appear to be deteriorating while others are intact and may continue to replace cuticle shed in later molts [27]. The air sacs have some bridging trabeculae that were probably formed by fusion of small air sac components with larger ones. The hemolymph channel contains much cell debris, apparently from the double row of precursor cells that were previously aligned between the developing air sacs. The width of the hemolymph channel here is $\sim 4 \mu \mathrm{m}$, i.e., the approximate width of two epithelial cells side-by-side.

Figure 17 provides further evidence that the width of the hemolymph channel may be related to the width of two precursor cells. While many precursor cells deteriorate (Figures 12,16), others remain as part of a thin 


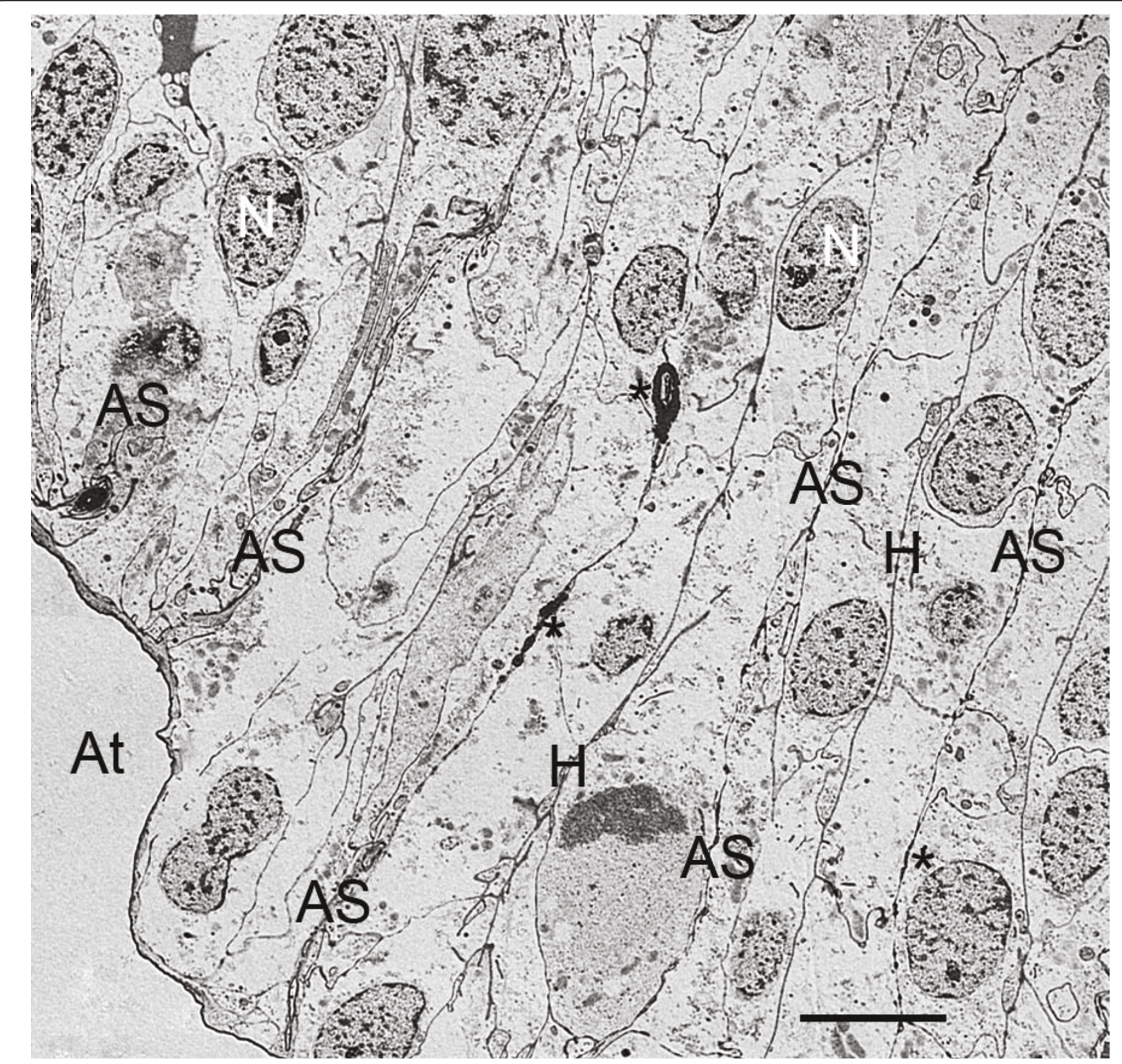

Figure 6 Atrial lumen (At) with early indications of air sacs (AS) that are separated by double rows of aligned cells. First instar, Centruroides gracilis. TEM. In some places closer to the atrium, the cells are releasing elongate fragments of cytoplasm as an early step in the development of the air sacs while farther inward there are only dense secretions (asterisks) that show the initial site of air sac formation (Fig. 5). No widening of the air sac entrance is evident at the sites where these early air sacs are forming. In these early stages, it is often difficult to identify where the air sac and hemolymph channels will be formed among the cells. N, nucleus; H, primordial hemolymph channel. Scale, $5 \mu$ m.

epithelium attached to the air sac wall (Figures 15, 16) [27]. The two cells in Figure 17 have made contact across the hemolymph space. They may be primordial pillar cells described as the space holders for the hemolymph channels of adult book lungs in scorpions and spiders [30,45,47-50].

Cells with large $(\sim 1 \mu \mathrm{m}$ dia.), electron-opaque granules did not appear to be abundant among the book lung tissue in the early stages of this investigation. Short lengths of air sacs contain these granules (Figures 3,11), but most primordial air sacs are formed from secreted cell fragments that lack such granules (Figures 2A, B and $3,8,9,10)$. Some granular cells were seen in the hemolymph channels of the book lungs of second instars. These are probably hemolymph-borne granulocytes; their presence is expected as the book lungs become functional for the active and foraging second instars. There may be different types of these granular cells, although their morphology is similar in the stages examined herein. Granulocytes have been described in 


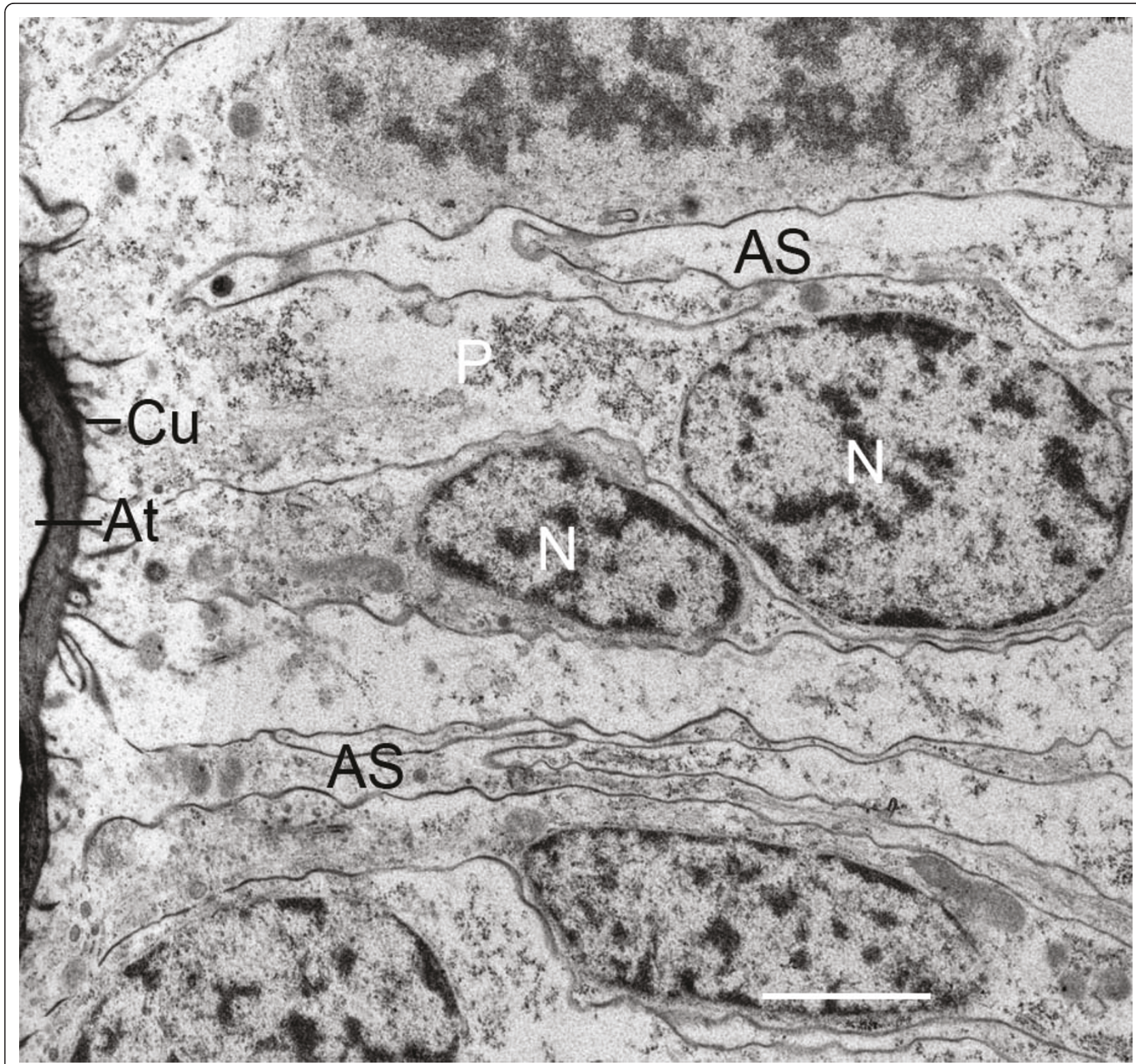

Figure 7 Cell fragmentation as an early stage in the development of air sacs (AS) among double rows of book lung precursor cells. No widening of the air sac entrance is evident at the origin of the air sacs in the cuticular wall (Cu) of the atrium (At), but two streams of elongate cell fragments separate a double row of cells from adjacent rows. The cells contain many small particles (P), possibly ribosomes and/or granules. The latter may contribute to the formation of air sac cuticle in later stages (e.g., Figs. 12, 13). N, nucleus. Scale, $2 \mu \mathrm{m}$.

scorpion hemolymph [51,52], and an investigation with TEM showed the opisthosomal lateral lymphoid and supraneural glands are likely sources of such cells [52].

\section{Discussion}

Epithelial cell invagination, proliferation, ingression and alignment

As reviewed by Fristrom [44], epithelial cells are characterized by a stable apical-basal polarity that is maintained throughout development, and their lateral surfaces have intercellular junctions that connect them to adjacent cells. In recent years, there is much research on the molecular basis for the polarity in epithelial cells [53-58] as well as their intercellular junctions [44,55,57,59-61]. Tyler [62] concludes that epithelial cells appear first in the Eumetazoan blastula and are a prominent feature in subsequent adult tissues. The characteristic apical-basal polarity of these cells, a critical factor in the present investigation, may also have arisen very early in stem metazoans.

Epithelial cells commonly exist in sheets and provide protective coverings and barriers for the external surface 


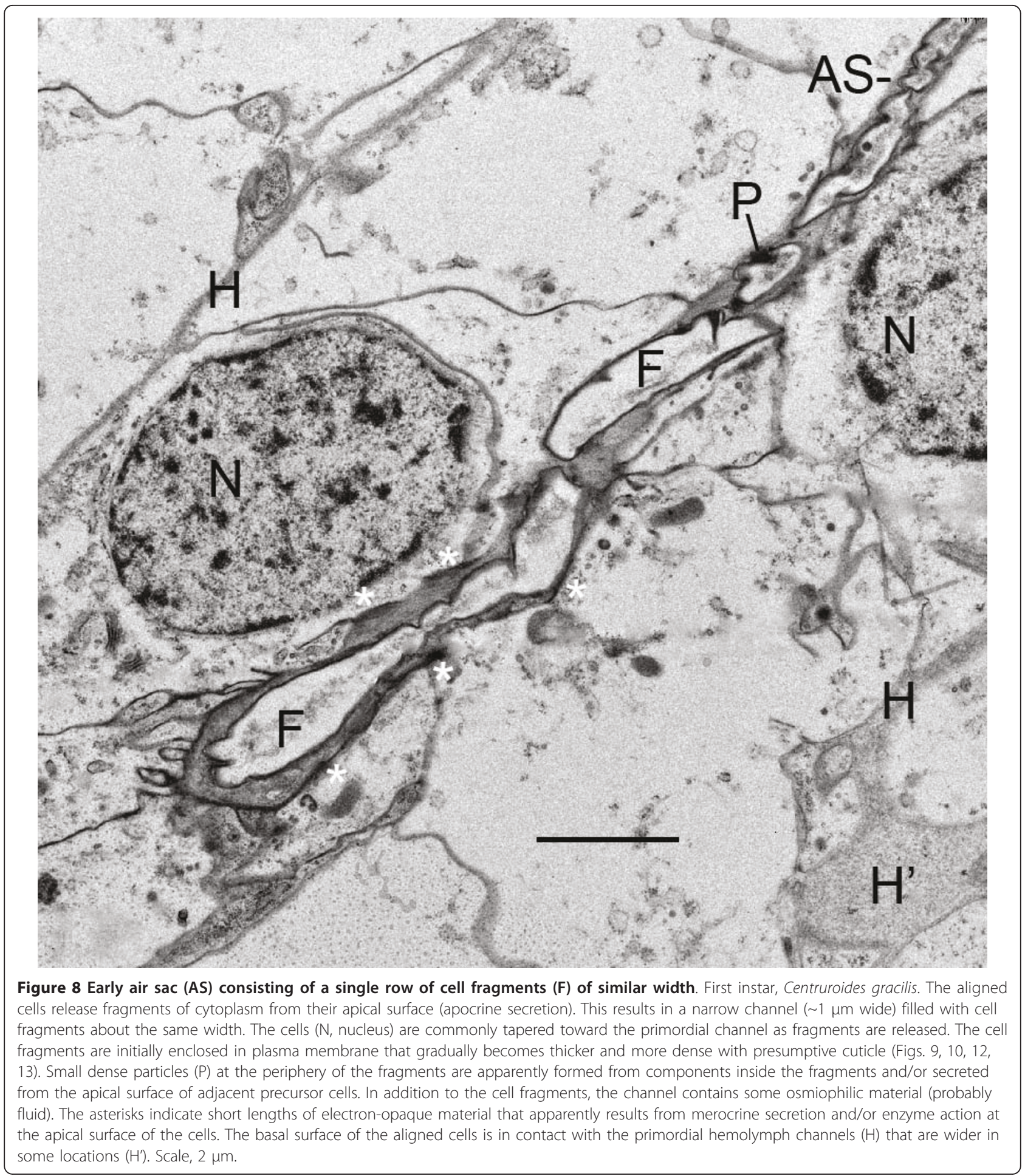

and for tubes, vessels and channels inside the animal. They are commonly in a single layer with a basement membrane secreted from their basal surface. Fristrom [44] notes that invertebrates sometimes have epithelial cells without a basement membrane, i.e., the cell basal surfaces are directly in contact with hemolymph as in Figures 15, 16 and 17. In arthropods, including scorpions, an important and typical example of epithelium is the hypodermal layer that secretes and replaces the cuticle and forms many external and internal structures [1,63-69]. 


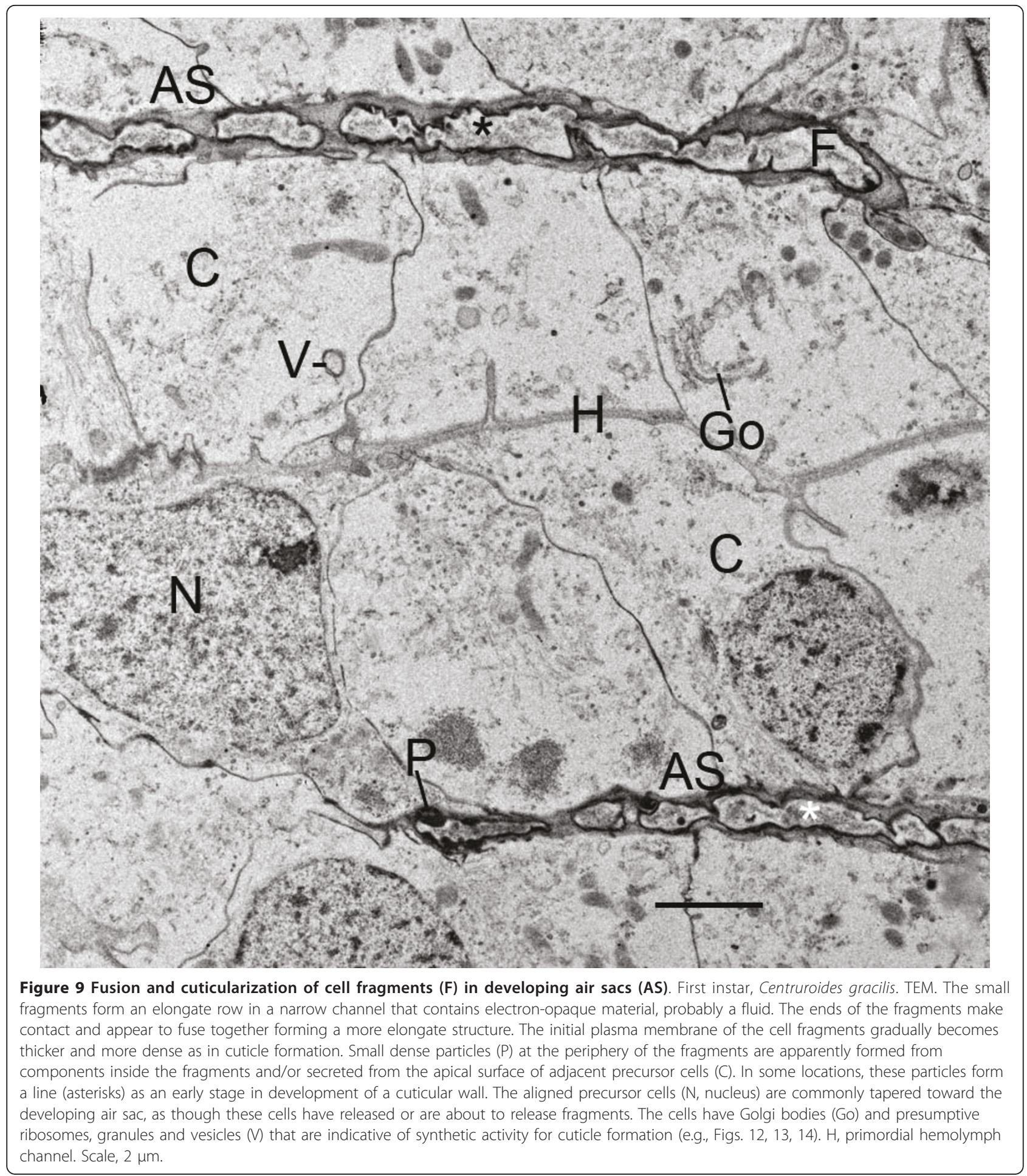

Epithelial cells undergo many different morphological changes during development; invagination of a specific region of the epithelium (Figures 1, 2A, B) is a common example $[44,55]$. The invagination often results from constriction of the apical ends of the cells [70,71] with the apical ends lining the concave surface, e.g., the atrial cavity of book lungs (Figure 2A, B). In scorpion embryos, the atrial wall initially consists of a layer of hypodermal cells with a basement membrane at their basal surface (Figure 2A, B).

As explained in Background, the invagination or infolding of the atrial epithelium for each lamella of 


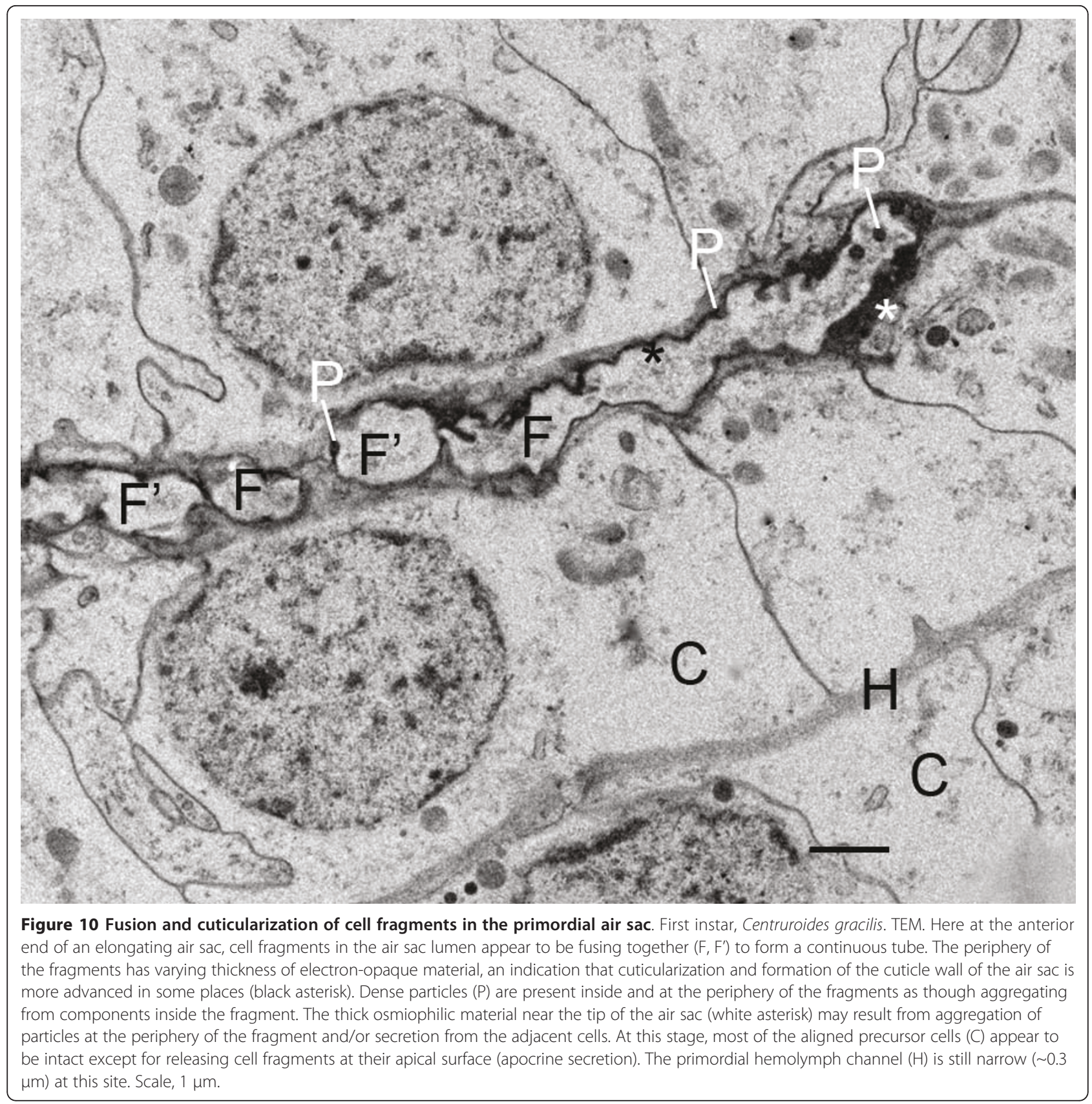

arachnid book lungs was proposed to be a continuation of the small amount of invagination that may occur along with outgrowth (evagination) in the formation of book gills of horseshoe crabs [7]. Slight widening at the atrial origin of some spider air sacs was hypothesized to be an indication of atrial wall infolding to provide the aligned precursor cells for each air sac $[8,9,18-21]$. In other light microscopic studies of spider embryos $[23,24]$, the authors noted some air sac widening at the atrial wall, but this was not considered a necessary or characteristic feature of air sac development.
In the present investigation, widening of the air sac entrance was seen at the atrial origin of some advanced lamellae (Figures 2B, 3) but not in the earliest stages of lamellar formation (Figures 2A, 6, 7). Without folds or invaginations from the atrial wall, the epithelial cells in scorpion embryos appear to proliferate, ingress (migrate inward) and organize themselves into parallel rows anterior to the atrium (Figures 2A, B and 3,5). Epithelial ingression is a common developmental process involving breakage of cell-cell adhesions, migration out of the epithelial layer and formation of new cell-cell adhesions 


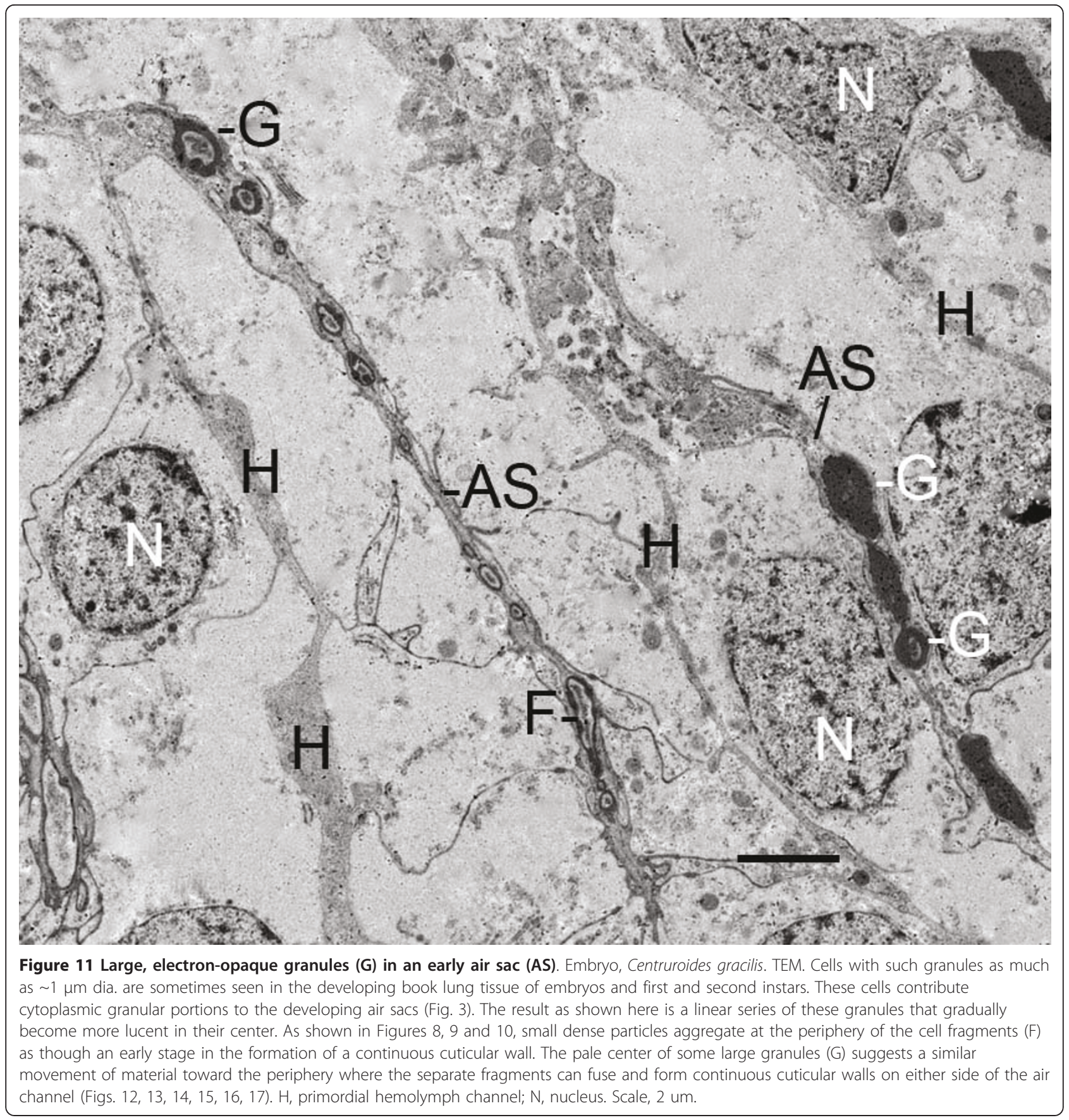

$[44,55,72]$. As in Figures 2A, B and 3, there is typically a loss of the basement membrane at the site of migration from the epithelium [44].

Among vertebrates and invertebrates, the ability to form a single row or layer of cells is a common feature of epithelial morphogenesis [44,72-74]. Often a single row, layer, cavity, tube or branching tube (e.g., tracheae, bronchi, blood vessels) is formed, while in book lungs the precursor cells organize themselves into multiple, nonbranching rows parallel to each other. The book lungs thus have much surface area for gas exchange without the added complexity of epithelial branching. A comparable nonbranching tracheal structure is the sieve trachea of spiders (Mysmenidae) such as Calodipoena incredula and Mysmenella samoensis (formerly Mysmena incredula and M. samoensis respectively $[37,75]$. Here, clusters of parallel, tubular tracheae extend forward from a common atrium. 


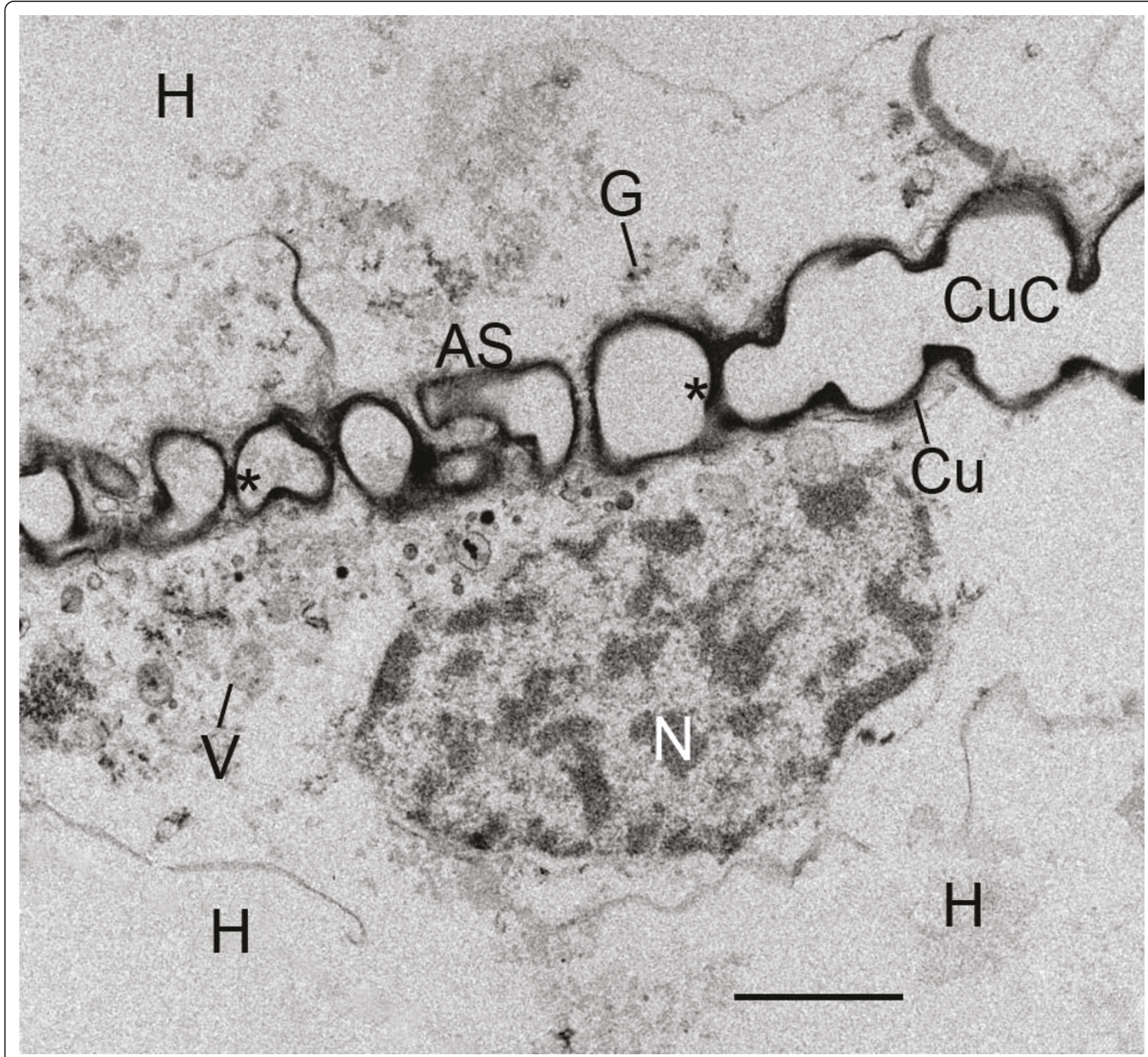

Figure 12 Formation of space holders (asterisks) and longer lengths of air sacs as a result of fusion and cuticularization of former cell fragments, now cuticle-enclosed components (CuC) of the air sac. First instar, Centruroides gracilis. TEM. Compared with earlier stages (Figs, $8,9,10,11)$, the outer wall of these components is now relatively thick $(\sim 0.1-0.2 \mu \mathrm{m})$ and dense. The walls of these components appear to fuse (asterisk) and form a bridging trabecula (space holder) that helps hold the developing cuticular walls in place (Figs. 13, 15, 16, 17). Many of the aligned precursor cells like this one ( $\mathrm{N}$, nucleus) release their contents and deteriorate (holocrine secretion) between the developing air sacs, thereby resulting in hemolymph channels $(H)$ with increasing width and space for passage of fluid. Granules $(G)$ and vesicles $(V)$ from these cells appear to increase the thickness of the cuticular walls (Cu, Fig. 13) of the developing air sacs. Scale, $2 \mu \mathrm{m}$.

\section{Epithelial cell polarity, secretion and lamellar formation} Initially in their ingression from the atrial epithelial layer, the book lung precursor cells have irregular shapes and show no sign of polarity (Figures 2A, B and $3,4)$. Like epithelial-derived cells elsewhere (e.g., exocrine glands, tracheae, bronchi) [44], the aligned cells anterior to the atrium soon show evidence of atrialbasal polarity, i.e., secretion from the apical surface (Figures $5,6,7,8,9,10,11)$ while the basal surface is in contact with the nutrient source (hemolymph). The enzymes and molecular components for the exoskeleton are secreted from the apical surface of the parent hypodermal cells $[1,29,63-69]$, and the material for the cuticle of the air sacs is secreted from the apical surfaces of the aligned book lung precursor cells (Figures 5, 6, 7, 8, 9, $10,11)$.

As the aligned cells begin to release material from their apical surface, their atrial-basal polarity results in 


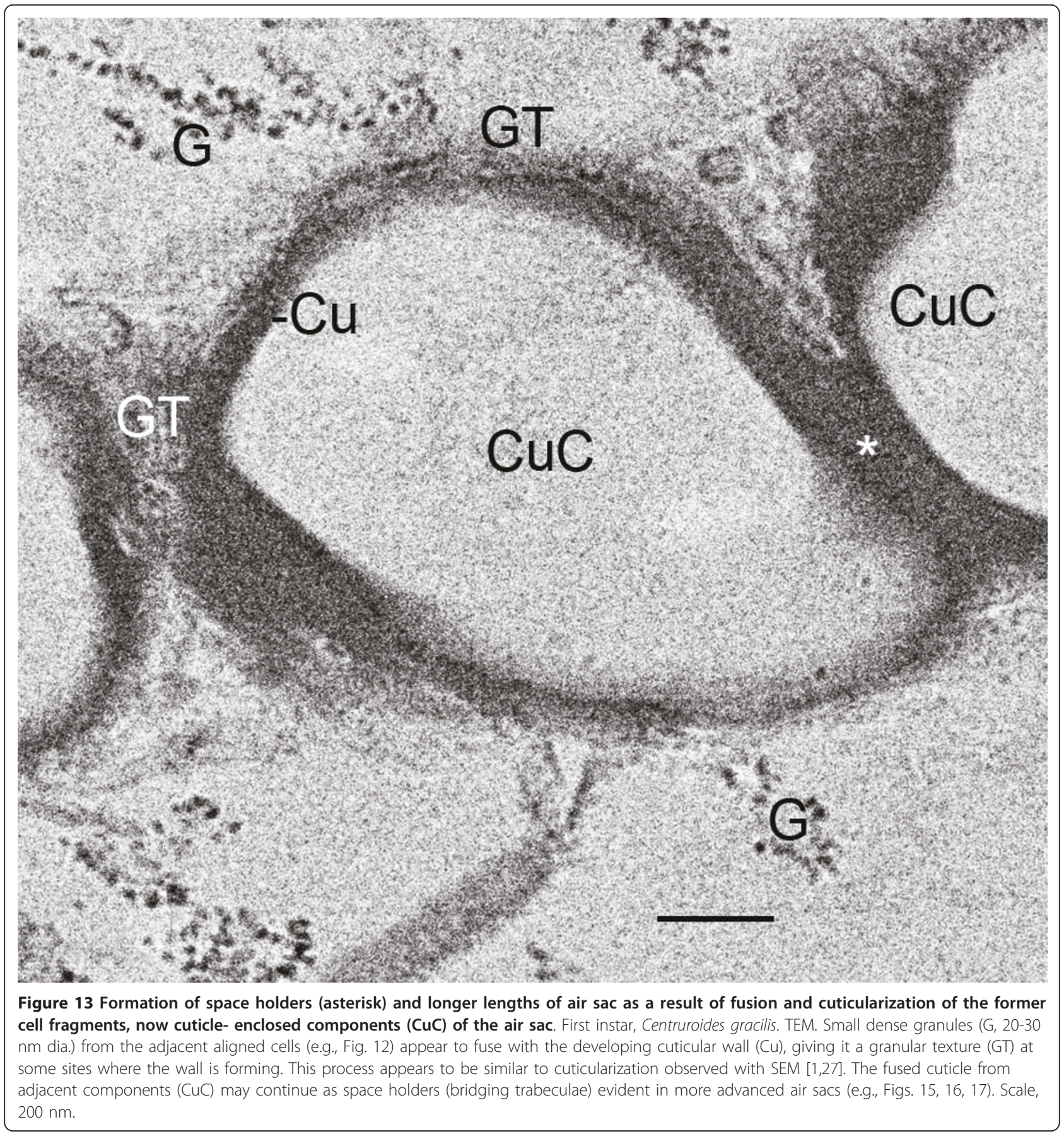

double rows of cells separated by primordial air sacs (Figures 5, 6, 7, 8, 9, 10, 11). The apical secretion produces the air sacs while the hemolymph channels form at the opposed bases of the aligned cells. The release of electron-opaque material (Figures 5, 6; presumptive merocrine secretion) and cell fragments (Figures 6, 7, 8, $9,10,11$; apocrine secretion) is characteristic of the early stages of lamellar formation. In more advanced stages, entire cells are disrupted, releasing granules and vesicles (holocrine secretion) that apparently contribute to the thickening cuticular walls of the air sacs (Figures $12,13,14)$.

While secretion from the apical surface of epithelial cells is a common feature [44,76-79], the cellular process of air sac formation is distinctive as described here for scorpions. The released cell fragments are similar in 


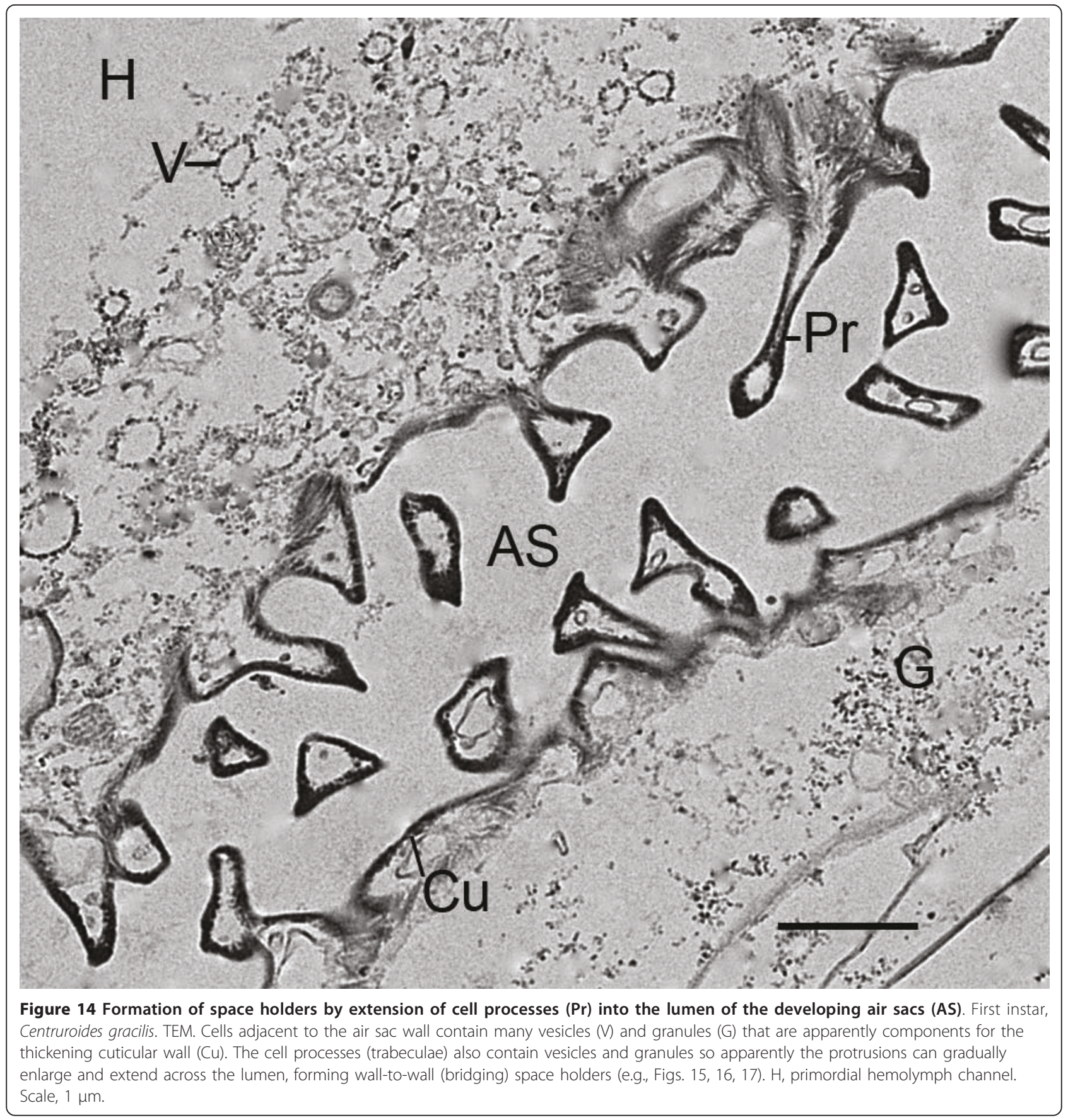

width among the aligned cells (Figures 8, 9, 10, 11), and the fragments fuse together to form an elongate channel (Figures 8, 9, 10, 11, 12, 13, 15, 16) with gradually thickening cuticular walls. A similar process of lamellar formation may occur in other arachnids as suggested from recent [50] and early studies of book lung lamellae in adults $[8,9,21,23,24,45]$.

For scorpion book lung lamellae, the cell fragments are initially enclosed in a typical plasma membrane (Figures
$6,7,8)$. Later, the covering of the fragments appears thicker and more dense as though cuticle is forming. The electron-opaque structures in the micrographs give some indication of how cuticularization occurs, but the process is uncertain. There are electron-opaque particles at the periphery of the fragments as though material in the fragment has begun to aggregate and/or form cuticle by enzyme action (Figures 9, 10,11). These peripheral particles and the dense and thickened fragment walls may 


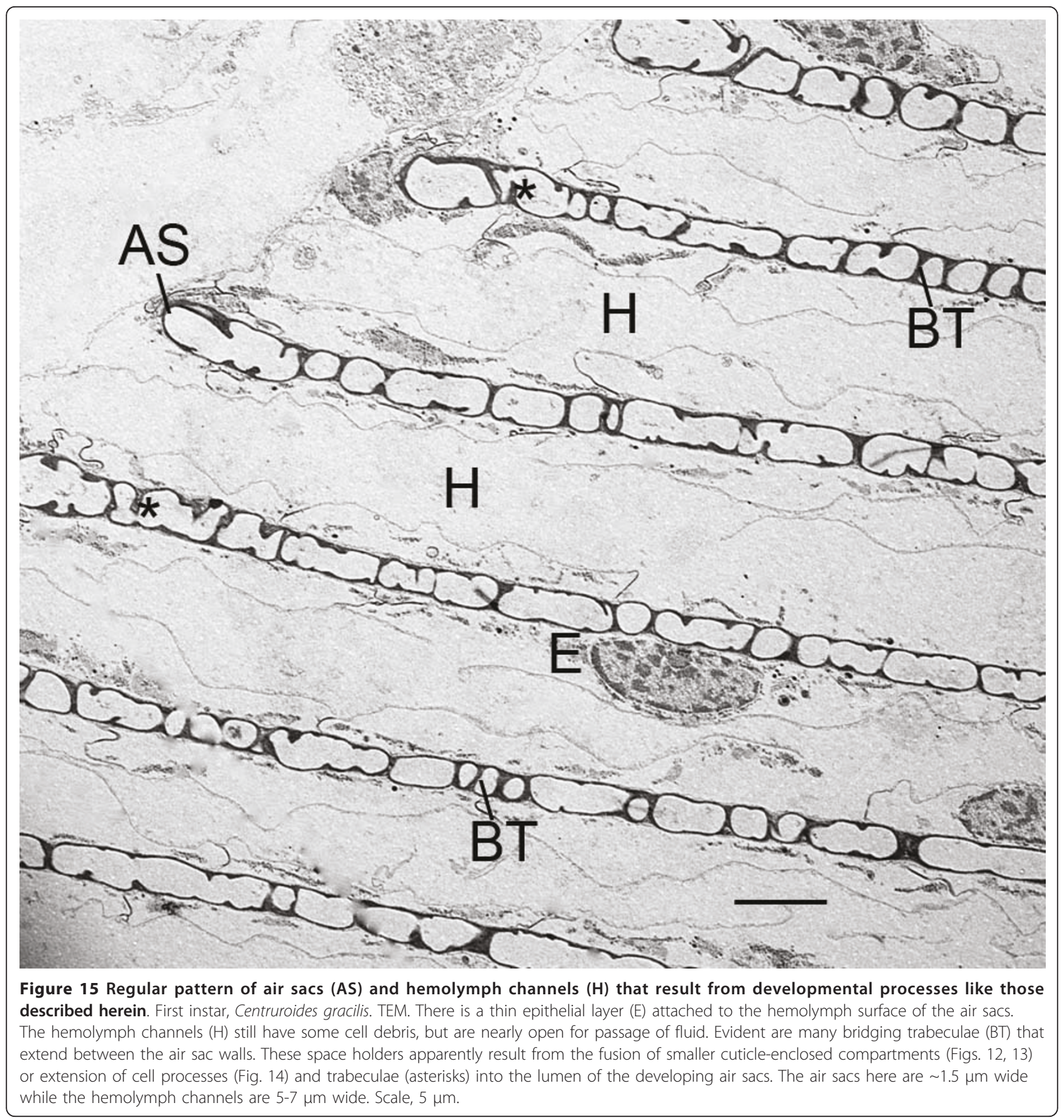

also be all or partially formed from the contents of fluid in the narrow and elongate lumen that contains the cell fragments (Figures 8, 9, 10, 11). Whatever the process, the cuticular wall of the air sac components is 50-200 nm thick in Figures 12 and 13.

As described above, an important feature of cuticularization is the apparent aggregation and/or formation of cuticle at the periphery of the cell fragments where fusion of the fragments can result in a continuous cuticle wall. The cells with large, electron-opaque granules may add larger quantities of cuticle primordia to the developing air sacs (Figures 3, 11), i.e., the peripheral coalescence of the presumptive cuticle material (Figure 11) helps form a continuous wall from the fused cell fragments in the developing air sac.

In an earlier study with SEM, entire small cells appeared to become aligned and enclosed within the cuticular walls of the developing air sacs [27], while in the present investigation with TEM the air sacs are formed from cell fragments of larger aligned cells. This 


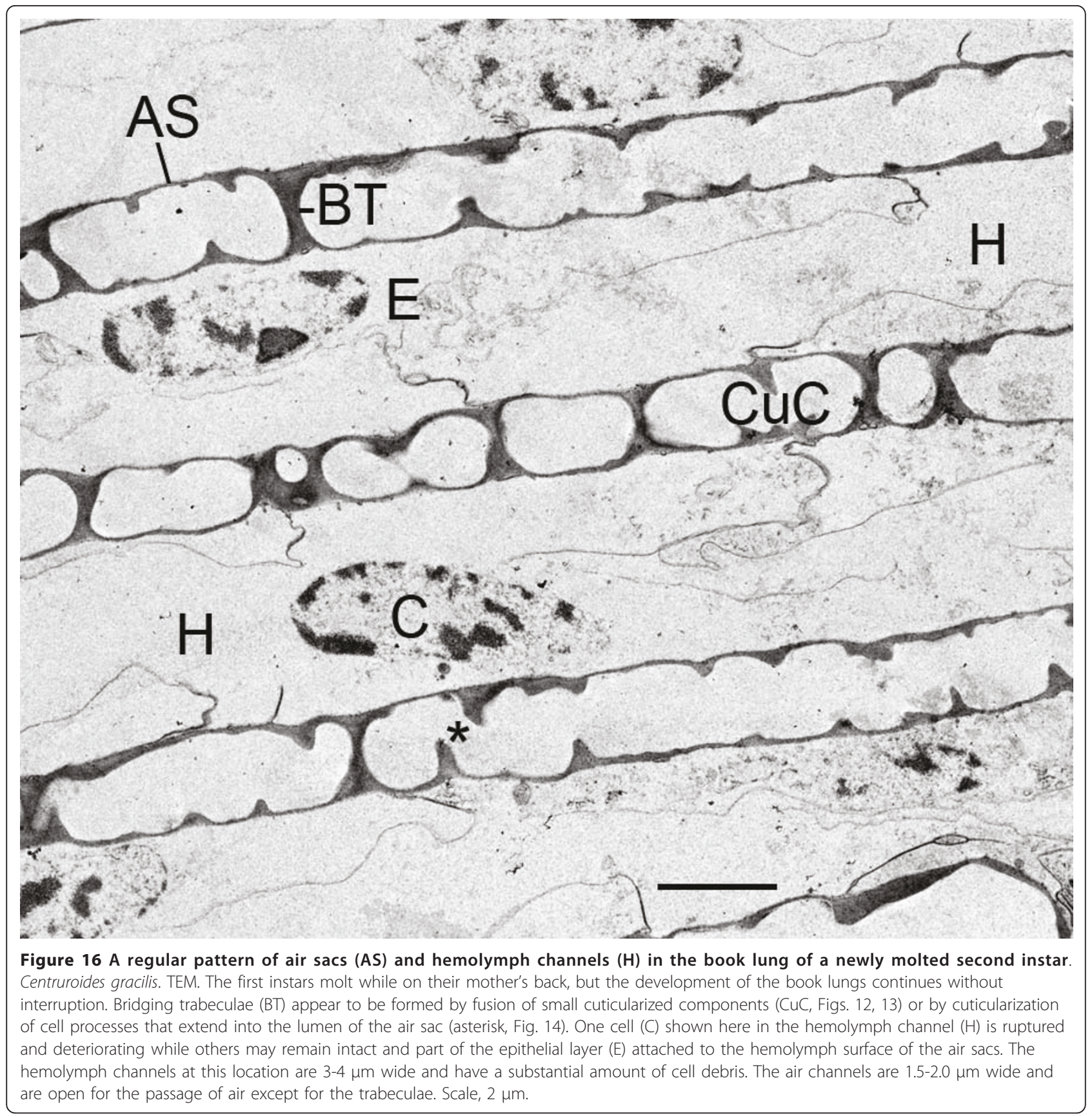

difference in cell contribution to lamellar formation results from a difference in the stage of development and the location within the book lung where the developmental process is viewed with the two different types of microscopes. Most of the sections in the present study were taken at an early stage and parallel to the aligned cells and developing lamellae. The earlier SEM study [27] showed the dorsal surfaces of lamellae at successive stages of development.
In the present investigation, the lamellar precursor cells are 3-8 $\mu \mathrm{m}$ in width (Figures $2 \mathrm{~A}, \mathrm{~B}$ and 3, 4, 5, 6, $7,8,9,10,11,12,14,17)$ while the primodial air sacs are much smaller, increasing in width from $\sim 0.5 \mu \mathrm{m}$ (Figures 5, 6) to 2-3 $\mu \mathrm{m}$ (Figures 9, 10, 11, 13, 14, 15, $16,17)$. Cell fragments rather than entire cells become part of the early air sacs. In the TEM sections observed herein, small cells $2 \times 4 \mu \mathrm{m}$ were sometimes seen among the larger ones, but they were not seen to 


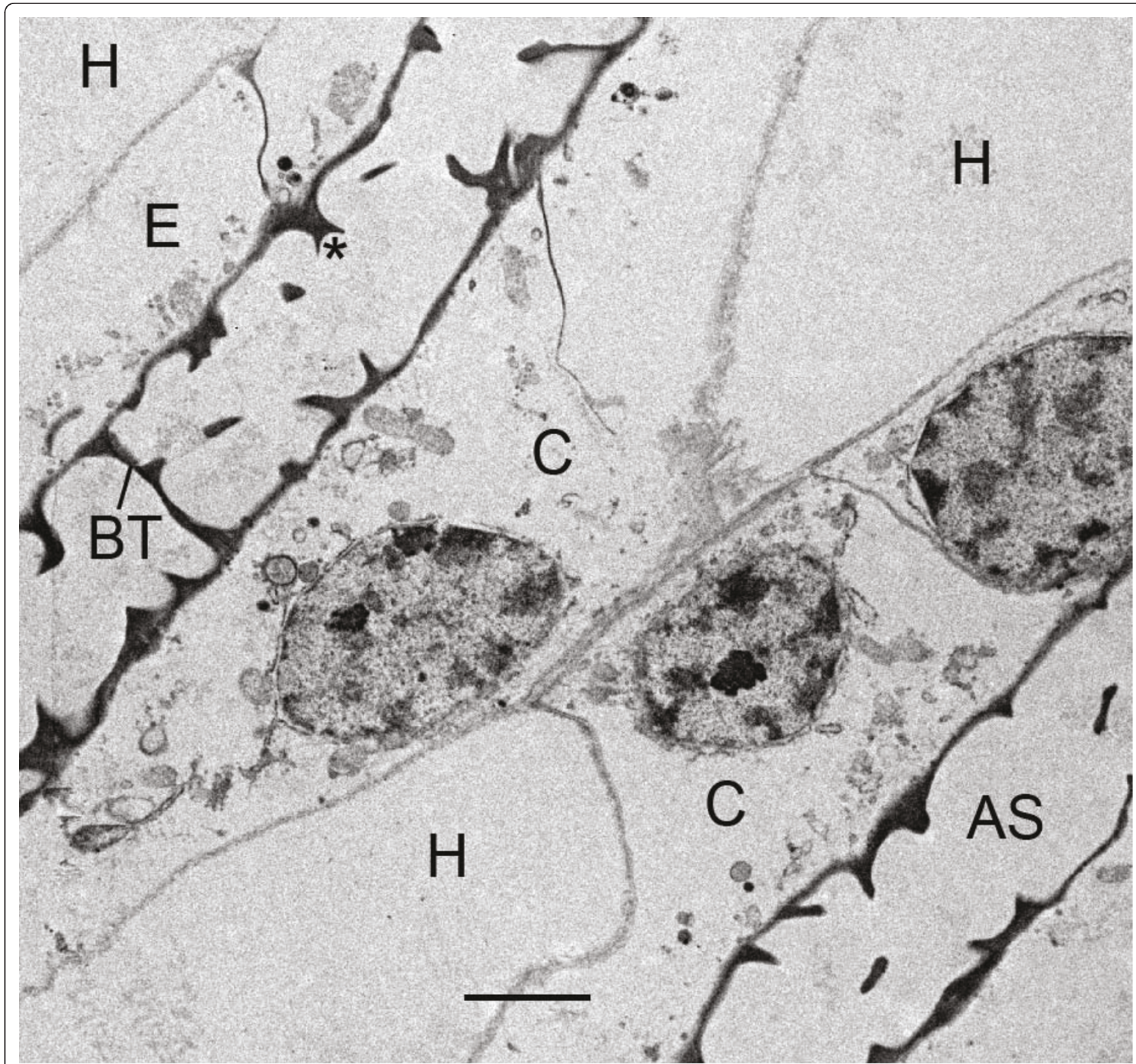

Figure 17 Presumptive primordial space holder across the hemolymph channel $(\mathrm{H})$ of a second instar book lung. Centruroides gracilis. TEM. Many cells deteriorate in the primordial hemolymph channel (Figs. 12, 16), resulting in space for passage of hemolymph. The two intact cells (C) shown here make contact across the channel lumen. These may be precursor pillar cells for the pillar type space holders that earlier workers report are a common feature in the book lung hemolymph channels of adult scorpions and spiders [30,45,47-50]. AS, air sac; BT, bridging trabeculae; asterisk, non-bridging trabecula. Scale, $2 \mu \mathrm{m}$.

become enclosed within the developing air sacs. In the early stages, each row of cell fragments is $\sim 1 \mu \mathrm{m}$ dia. or less, so even the smallest cells are too large to become part of the early air sac.

In the earlier study with SEM [27], it appears that the lamellae are increased in length, height and number by addition of material at (respectively) the anterior, dorsal and lateral edges of the book lung. A porous membrane overlies the dorsal surface of the book lungs $[80,81]$, and this was removed so the SEM could be used to view the developing lamellae from the dorsal aspect. The growth regions of the book lung, thus exposed, have many small cells $2 \times 4 \mu \mathrm{m}$, and these small cells appear to become aligned and surrounded by cuticle as they become part of the vertical growth of more advanced and wider $(2-3 \mu \mathrm{m})$ lamellae. Openings in the lamellae showed cells and/or large granules deteriorating and apparently providing cuticle components [27]. 


\section{Development of space holders}

As pointed out by Farley [1,27] book lung space holders are described in numerous earlier papers; most helpful is the comprehensive treatise by Kamenz and Prendini [30]. The present investigation is the first to provide ultrastructural information about the formation of book lung space holders in the early stages of development.

In the book lungs of adult scorpions, the proximal one-third to one-fifth of the air sac lamellae have bridging trabeculae while the remaining distal portion has other types of nonbridging trabeculae that are firmly attached to only one wall of the air sac [30]. As reported in that study, for adult Centruroides gracilis the distal part of each lamella has a reticulate network of cuticular veins that serve as nonbridging space holders while bridging trabeculae are present in the smaller proximal part of the lamellae. A similar lamellar pattern of bridging and nonbridging trabeculae is present in adult spiders. For spider lamellae, Purcell [8] concluded that the proximal portion with bridging trabeculae is formed by new growth during the preceding intermolt period, while the distal part of the lamellae has nonbridging trabeculae attached to only one wall because there is temporary obstruction by the lamellar exuvium during the molt.

The replacement of book lung cuticle has not yet been studied in advanced scorpion instars, but present results suggest that Purcell's [8] hypothesis may be applicable. The lamellae in adult Centruroides gracilis have different proximal and distal trabeculae [30] as in spiders, but in the present investigation with embryos and early instars, only partial or complete bridging trabeculae were seen (Figures 15, 16, 17). These trabeculae probably provide much stability for air sac walls in the early stages of development when lamellar exuvia and replacement cuticle are not yet factors.

The bridging trabeculae in scorpion embryos and first instars may be formed by the fusion of smaller components in the developing air channels (Figures 12, 13). In more advanced stages, the lamellae have regions where it appears that air sac components fused with others, and bridging trabeculae were formed in the process (Figures 15, 16). In Figures 15, 16 and 17, partial trabeculae are common, but it is not clear if they result from sectioning of a bridging trabecula and/or incomplete wall-to-wall growth.

Figure 14 shows the development of trabeculae by extension of cell processes into the lumen of the developing air sac. The cell processes and adjacent cellular debris contain vesicles and granules that may contribute to cuticularization and extension of the processes to the opposing wall. Space holders are being formed here from processes that extend inward from both walls of the air sac rather than one wall as occurs for nonbridging trabeculae [30]. In the opisthosomal appendages and book gills of the horseshoe crab, trabeculae are formed by cuticularization of cell processes from the adjacent epithelial (hypodermal) cells [1].

Space holders are much less common in the hemolymph channels as compared with the many trabeculae in the air sacs [27]. In adult horseshoe crabs and adult scorpions and spiders, the hemolymph space holders are mainly cellular pillars, i.e., conjoined extensions of pillar cells from opposed cuticle walls [30,47-50]. Examples that may be the initial formation of cellular pillars are provided in Figure 17 and earlier investigations $[1,27]$. The two conjoined cells of Figure 17 span the hemolymph channel and may be retained as pillar cells, while most of the cells in the primordial hemolymph channel become part of the epithelium attached to the air sac wall (Figures 15, 16, 17) or they deteriorate and thereby leave space for hemolymph (Figures 12, 16).

\section{Comparison of book gill and book lung development}

In spider embryos, the spiracles, atrium and primordial air sacs develop posterior to opisthosomal limb buds; book gills are formed from the posterior surface of opisthosomal limb buds of the horseshoe crab $[1,6-9,18,20,21,45]$. In scorpion embryos, the limb buds have completely disappeared, except for those that become the genital operculum and pectines, before spiracles are evident on the ventral surface of opisthosomal segments 4-7 (Figure 1) [27,40-43]. This does not negate the possibility of book gill/book lung homology, since embryo development is often modified for the benefit of the embryo [[82], p. 128], as demonstrated by the substantial developmental adaptations for oral feeding in the more derived scorpion families [65,83-86].

As described above, infolding or invagination of the atrial epithelium was not evident herein as a source of the precursor cells for each lamella. Rather, there is ingression of cells from the atrial epithelium (Figures $2 \mathrm{~A}, \mathrm{~B}$ and 3 ), and their subsequent alignment, apicalbasal polarity and secretion result in the highly ordered lamellae of the book lungs (Figures 15, 16). These developmental cell processes produce an arrangement of cells and lamellae that would have occurred if infolding of the atrial epithelium had been the source of the precursor cells for each lamella. This raises the possibility that such infolding was an ancestral condition that initiated lamellar formation but is no longer evident in extant scorpions. This hypothesis, however, requires replacement of epithelial infolding with ingression in the evolutionary history of the book lungs.

In the horseshoe crab, the outgrowth (evagination) of the book gill lamellae from the posterior surface of opisthosomal branchial appendages differs substantially from the ingression process in extant scorpions (Figures $2 \mathrm{~A}, \mathrm{~B}$ and 3$)[1,6,7]$, but tissue sections and TEM 
studies are needed to provide further clarification of cell activity in the formation of book gills. Book gill development has been studied only with light microscopy $[6,7,87]$ and SEM [1] in the early stages of development; information is lacking about the ultrastructure of book gill and book lung formation in later instars before and after molts.

As pointed out by Fristrom [44], epithelial cells are transformed into nonpolarized mesenchyme cells during gastrulation, but most commonly the epithelial-derived cells have apical-basal polarity in their new location as did the parent cells. This means that caution should be used in inferring homology among similar patterns of epithelial cells. Wherever they occur in animals, epithelial cells tend to form sheets, layers and tubes, and their apical-basal polarity and organizational patterns are apparently very ancient [62]. Thus, organs with a similar epithelial structure are not necessarily indicative of a common ancestor (e.g., epithelial-derived exocrine glands in vertebrates and invertebrates, tracheae and bronchi, insect and spider tracheae).

The precursor cells for book gills are aligned in rows by hypodermal evagination $[1,7]$ while ingression and alignment occur for scorpion book lungs (Figures 2A, B, $3,5,6,7)$. Once positioned, the precursor cells have some similar activities in the development of book gill [1,7] and book lung lamellae: 1) cell proliferation, 2) shaping of cuticular structures as a result of cell growth and positioning relative to each other, 3) alignment of cells side-by-side into rows as commonly occurs in the hypodermis, 4) apical-basal polarity in these aligned cells like that in the hypodermis, 5) cell synthesis, transport and release of material for cuticle and 6) the cellular formation and cuticularization of space holders.

The results in this and earlier studies with SEM $[1,27]$ thus provide evidence pro and con for book gill/book lung homology, depending on how much emphasis is given to the specific developmental differences and similarities. Page-like lamellae are the result for both respiratory organs, but both are formed from a cell type (epithelium) that typically forms ducts, tubes, layers and channels in a diversity of animals and organs.

\section{Epithelial morphogenesis}

Numerous model systems (e.g., tracheae, zebrafish sense organs, bronchi, kidney tubules, vertebrate neural crest, blood vessels) are presently being used to study the cellular and molecular basis of epithelial morphogenesis [70-74]. Cell activity with some stages like those of book lung precursor cells occurs in an in vitro model using Madin-Darby canine kidney (MDCK) epithelial cells [73]. Starting from a cyst with a wall consisting of a single layer of polarized (apical surface inward) epithelial cells, cells can be stimulated to proliferate, ingress outward from the wall and align side-by-side. The apical surface of these aligned cells gradually produces a tubular lumen extending outward from the lumen of the original cyst. The resulting structure is somewhat like the air sacs extending anteriorly from the scorpion atrium.

Among the model systems, tracheal development in Drosophila is receiving much attention for the genetic determination of cell activity during tubulogenesis [74,88-90]. Some of the same genes and cell processes involved in the formation of fruit fly tracheae are implicated in the development of tubular structures in vertebrates [90]. Cellular and genetic research for fruitfly tracheae may be helpful for understanding book lung development in scorpions since there are similar processes of epithelial morphogenesis in the formation of these respiratory organs: 1) invagination of hypodermis in forming the atrium, 2) cell migration, 3) expression of apical-basal polarity, 4) alignment of cells side-by-side and presumably with formation of new cell-cell connections, 5) secretion from the apical surface to form a lumen and 6) emptying of the lumen to allow passage of air $[74,76,91]$.

The development of arachnid book lungs is another example of epithelial morphogenesis with some features well suited for comparative studies. The book lungs are relatively large and tractable, even in embryos. There are 2 , 4 , or 8 book lungs in each individual $[1,30,49,50]$. Lamellar development is a continuing process in successive molts, and within each book lung the same cell processes are apparently repeated to make numerous lamellae [27]. Finally, lamellate respiratory organs are important for our understanding of evolutionary history and taxonomic relationships [11,30,49,50,75,92-94].

\section{Conclusions}

The results herein show that some cellular activities are similar for book gill and book lung formation, but there are also important differences. The present investigation thus provides evidence for and against the hypothesis for book gill/book lung homology. The features of cell alignment and apical-basal polarity described herein are common among epithelial cells in animals, but the precursor cells for book gills and book lungs are distinctive in organizing themselves into a compact mass of many parallel, non-branching rows, i.e., the page-like pattern of alternating hemolymph and air or water channels.

The genetic and molecular basis of epithelial morphogeneis is presently receiving much research attention using model systems such as the tracheae of Drosophila. Book lung formation in scorpions is another example of epithelial cell morphogenesis, and many genetic and molecular features now being demonstrated in model systems in other animals may also be applicable for the development of book lungs. 


\section{Acknowledgements}

The comments and suggestions of the editor and reviewers are much appreciated. For sectioning and staining for TEM and assistance in using the electron microscope, special thanks to Steven McDaniel, Staff Research Associate in the Central Facility for Advanced Microscopy and Microanalysis at the University of California, Riverside. Also much appreciated for locating needed literature, the staff of Interlibrary Loan Services, Orbach Science Library, University of California, Riverside. This research was funded by intramural grants from the University of California.

\section{Competing interests}

The author declares that he has no competing interests.

Received: 19 April 2011 Accepted: 27 July 2011 Published: 27 July 2011

\section{References}

1. Farley RD: Book gill development in embryos and first and second instars of the horseshoe crab Limulus polyphemus L. (Chelicerata, Xiphosura). Arth Struct Develop 2010, 39:369-381.

2. Laurie M: The embryology of a scorpion (Euscorpius italicus). Q I Microsc Sci 1890, 31:15-141.

3. Lankester ER: Limulus an arachnid. Q J Microsc Sci 1881, 21:504-548, 609649.

4. Lankester ER: A new hypothesis as to the relationship of the lung-book of Scorpio to the gill-book of Limulus. Q J Microsc Sci 1885, 25:339-342.

5. Lankester ER: Notes on certain parts in the anatomy and generic characteristics of scorpions. Trans Zool Soc, Lond 1885, 11:372-384.

6. Kingsley JS: Notes on the embryology of Limulus. Q J Microsc Sci 1885, 25:521-576.

7. Kingsley JS: The embryology of Limulus. Part II. J Morph 1893, 8:195-270.

8. Purcell WF: Development and origin of the respiratory organs in Araneae. Q J Microsc Sci 1909, 54:1-110.

9. Kassianow N: Die Frage über den Ursprung der Arachnoideenlungen aus den Merostomenkiemen (Limulus-Theorie). Biologisches Centralblatt 1914, 34:8-46, 108-149, 170-213, 221-247.

10. Pavlovsky EN: Studies on the organization and development of scorpions. 5. The lungs. Q J Microsc Sci 1926, 70:135-146.

11. Dunlop JA: The origins of tetrapulmonate book lungs and their significance for chelicerate phylogeny. In Proceedings of the 17th European Colloquium of Arachnology: 1997; Edinburgh. Edited by: Selden PA. Burnham Beeches, Bucks, UK: British Arachnology Society; 1998:9-16.

12. Jeram AJ: Paleontology. In Scorpion Biology and Research. Edited by: Brownell PH, Polis GA. Oxford/New York: Oxford University Press; 2001:370-392.

13. Popadić A, Abzhanov A, Rusch D, Kaufman TC: Understanding the genetic basis of morphological evolution: the role of homeotic genes in the diversification of the arthropod bauplan. Internat J Dev Biol 1998, 42:453-461.

14. Popadić A, Nagy L: Conservation and variation in Ubx expression among chelicerates. Evol \& Dev 2001, 3:391-396.

15. Damen WGM, Saridaki T, Averof M: Diverse adaptations of an ancestral gill: a common evolutionary origin for wings, breathing organs, and spinnerets. Current Biology 2002, 12:1711-1716.

16. Simonnet F, Deutsch J, Quéinnec E: Hedgehog is a segment polarity gene in a crustacean and a chelicerate. Dev Genes \& Evol 2004, 214:537-545.

17. Simonnet $F$, Célérier $M-L$, Quéinnec E: Orthodenticle and empty spiracles genes are expressed in a segmental pattern in chelicerates. Dev Genes \& Evol 2006, 216:467-480.

18. Simmons OL: Development of the lungs of spiders. Ann Mag Nat Hist, Ser 6 1894, 14:210-221.

19. Brauer A: Beiträge zur Kenntnis der Entwicklungsgeschichte des Skorpions, II. Zeitschrift für wissenschaftliche Zoologie 1895, 59:351-433.

20. Purcell WF: Note on the development of the lungs, entapophyses, tracheae and genital ducts in spiders. Zoologischer Anzeiger 1895, 18:396-400.

21. Ivanić VM: Über die Lungenentwicklung bei dipneumonen Araneinen. Zoologischer Anzeiger 1912, 40:283-289.

22. Dawydoff C: Développement embryonnaire des Arachnides. In Traité de Zoologie, Anatomie, Systématique, Biologie. Volume 6. Edited by: Grassé PP. Paris: Masson; 1949:320-385.
23. Montgomery TH Jr: On the spinnerets, cribellum, colulus, tracheae and lung books of Araneads. Proc Acad Nat Sci Phil 1909, 61:299-320.

24. Janeck R: Die Entwicklung der Blättertracheen und der Tracheen bei den Spinnen. Jenaische Zeitschrift für Naturwissenschaft 1909, 44:587-646.

25. Pechmann M, Khadjeh S, Sprenger F, Prpic N-M: Patterning mechanisms and morphological diversity of spider appendages and their importance for spider evolution. Arth Struct Develop 2010, 39:453-467.

26. Anderson DT: Embryology and phylogeny of annelids and arthropods. In International Series of Monographs in Pure and Applied Biology, Zoology Division. Volume 60. New York: Pergamon; 1973:365-451.

27. Farley RD: Development of respiratory structures in embryos and first and second instars of the bark scorpion, Centruroides gracilis (Scorpiones: Buthidae). J Morph 2008, 269:1134-1156.

28. Gaban RD, Farley RD: Ecdysis in scorpions: supine behavior and exuvial ultrastructure. Invert Biol 2002, 121:136-147.

29. Hjelle JT: Anatomy and morphology. In The Biology of Scorpions. Edited by: Polis G. Stanford, CA: Stanford University Press; 1990:9-63.

30. Kamenz $C$, Prendini $L$ : An atlas of book lung ultrastructure in the Order Scorpiones (Arachnida). Bull Am Mus Nat Hist 2008, 316:1-359.

31. Fahrenbach WH: Merostomata. In Microscopic Anatomy of Invertebrates. Chelicerate Arthropoda. Volume 8A. Edited by: Harrison FW, Foelix RF. New York: Wiley-Liss; 1999:21-115.

32. Latreille PA: ("An XII"), Histoire naturelle, générale et particuliére, des Crustacés et des Insectes. Ouvrage faisant suit aux oeuvres de Leclerc de Buffon, et partie de cours complet d'histoire naturelle redigée par C. S. Sonnini. Paris: De I'Imprimerie de F. Dufart; 18047.

33. Francke OF, Jones SK: The life-history of Centruroides gracilis (Scorpiones, Buthidae). J Arachnol 1982, 10:223-239.

34. Sissom WD, Lourenço WR: The genus Centruroides in South America (Scorpiones, Buthidae). J Arachnol 1987, 15:1-28.

35. Ades D: Notes sur des élevages et une reproduction du scorpion Centruroides gracilis (Latreille) (Scorpiones, Buthidae) de Key Largo (Floride). Arachnides 1998, 37:1-12.

36. Fet V, Sissom WD, Lowe G, Braunwalder ME: Catalog of the scorpions of the world (1758-1998). New York: New York Entomological Society; 2000, 105-107.

37. Platnick NI: The World Spider Catalog, Version 12.0.Edited by: Merrett $P$, Cameron HD. New York: American Museum of Natural History; 2000:[http:// research.amnh.org/iz/spiders/catalog/INTRO1.html].

38. Spurr AR: A low-viscosity epoxy resin embedding medium for electron microscopy. J Ultrastruct Res 1969, 26:31-43.

39. Reynolds ES: The use of lead citrate at high $\mathrm{pH}$ as an electron-opaque stain in electron microscopy. J Cell Biol 1963, 17:208-212.

40. Farley RD: Abdominal plates, spiracles and sternites in the ventral mesosoma of embryos of the desert scorpion Paruroctonus mesaensis (Scorpiones, Vaejovidae). Invert Reproduct Develop 2001, 40:193-208.

41. Farley RD: Development of pectines in embryos of Paruroctonus mesaensis Stahnke, 1957 (Scorpiones: Vaejovidae). In Scorpions 2001, In Memoriam Gary A. Polis. Edited by: Fet V, Selden PA. Burnham Beeches, Bucks, UK: British Arachnological Society; 2001:369-381.

42. Farley RD: Developmental changes in the embryo, pronymph, and first molt of the scorpion Centruroides vittatus (Scorpiones: Buthidae). J Morph 2005, 265:1-27.

43. Farley RD: Development of segments and appendages in embryos of the desert scorpion Paruroctonus mesaensis (Scorpiones: Vaejovidae). J Morph 2001, 250:70-88.

44. Fristrom D: The cellular basis of epithelial morphogenesis. A review. Tissue \& Cell 1988, 20:645-690.

45. Kästner A: Bau und Funktion der Fächertracheen einiger Spinnen. Zeitschrift für Morphologie und Ökologie der Tiere 1929, 13:463-558.

46. Lautié N, Soranzo L, Lajarille M-C, Stockmann R: Paraxial organ of a scorpion: structural and ultrastructural studies of Euscorpius tergestinus paraxial organ (Scorpiones, Euscorpiidae). Invert Reproduct Develop 2008, 51:77-90.

47. Berteaux L: Le poumon. La Cellule 1889, 5:255-316

48. Reisinger PWM, Tutter I, Welsch U: Fine structure of the gills of the horseshoe crabs Limulus polyphemus and Tachypleus tridentatus and of the book lungs of the spider Eurypelma californicum. Zoologische Jahrbücher, Abteilung für Anatomie und Ontogenie der Tiere 1991, 121:331-357. 
49. Kamenz C, Dunlop JA, Scholtz G: Characters in the book lungs of scorpions (Chelicerata, Arachnida) revealed by scanning electron microscopy. Zoomorph 2005, 124:101-109.

50. Scholtz G, Kamenz C: The book lungs of Scorpiones and Tetrapulmonata (Chelicerata, Arachnida): evidence for homology and a single terrestrialisation event of a common arachnid ancestor. Zoology 2006 109:2-13.

51. Ravindranath $\mathrm{MH}$ : The hemocytes of the scorpion Palamnaeus swammerdami. J Morph 1974, 144:1-10.

52. Farley RD: The ultrastructure of hemocytopoietic organs in the desert scorpion, Paruroctonus. Tissue \& Cell 1984, 16:577-588.

53. Wang AZ, Ojakian GK, Nelson WJ: Steps in the morphogenesis of a polarized epithelium. I. Uncoupling the roles of cell-cell and cellsubstratum contact in establishing plasma membrane polarity in multicellular epithelial (MDCK) cysts. J Cell Sci 1990, 95:137-151.

54. Wang AZ, Ojakian GK, Nelson WJ: Steps in the morphogenesis of a polarized epithelium. II. Disassembly and assembly of plasma membrane domains during reversal of epithelial cell polarity in multicellular epithelial (MDCK) cysts. J Cell Sci 1990, 95:153-165.

55. Schöck F, Perrimon N: Molecular mechanisms of epithelial morphogenesis. Ann Rev Cell Dev Biol 2002, 18:463-493.

56. Nelson WJ: Epithelial cell polarity from the outside looking in. News of Physiological Science 2003, 18:143-146.

57. Pilot F, Licuit T: Compartmentalized morphogenesis in epithelia: from cells to tissue shape. Developmental Dynamics 232:685-694.

58. Spiliotis ET, Hunt SJ, Hu Q, Kinoshita M, Nelson WJ: Epithelial polarity requires septin coupling of vesicle transport to polyglutamylated microtubules. J Cell Biol 2008, 180:295-303.

59. Borghi N, Nelson WJ: Intercellular adhesion in morphogenesis: molecular and biophysical considerations. Current Topics in Developmental Biology 2009, 89:1-32.

60. Harris TJC, Tepas U: Adherens junctions: from molecules to morphogenesis. Molecular Cell Biology 2010, 11:502-514.

61. Neubueser D, Hipfner DR: Overlapping roles of Drosophila Drak and Rok kinases in epithelial tissue morphogenesis. Molecular Biology of the Cell 2010, 21:2869-2879.

62. Tyler S: Epithelium - The primary building block for metazoan complexity. Integr Comp Biol 2003, 43:55-63.

63. Shrivastava SC: Molting in a scorpion. 1. Changes in the newly molted cuticle of Palamnaeus bengalensis. Ann Ent Soc Am 58:612-617.

64. Hackman RH: The integument of Arthropoda. In Chemical Zoology, Arthropoda, Part B. Volume VI. Edited by: Florkin M, Scheer BT. New York: Academic Press; 1971:1-62.

65. Farley RD: Scorpiones. In Microscopic Anatomy of Invertebrates, Chelicerate Arthropoda. Volume 8A. Edited by: Harrison FW, Foelix RF. New York: WileyLiss; 1999:117-222.

66. Merzendorfer $\mathrm{H}$, Zimoch L: Chitin metabolism in insects: structure, function and regulation of chitin synthases and chitinases. J Exp Biol 2003, 206:4393-4412

67. Konopová B, Zrzavý J: Ultrastructure, development and homology of insect embryonic cuticle. J Morph 2005, 264:339-362.

68. Merzendorfer H: Insect chitin synthases: a review. J Comp Physiol B 2006, 176:1-15.

69. Moussian B: Recent advances in understanding mechanisms of insect cuticle differentiation. Insect Biochemistry and Molecular Biology 2010, 40:363-375.

70. Martin AC, Gelbart M, Rodrigo F-G, Kaschube M, Wieschaus EF: Integration of contractile forces during tissue invagination. J Cell Biol 2010, 188:735-749.

71. Letizia A, Sotillos S, Campuzano S, Llimargas M: Regulated Crb accumulation controls apical constriction and invagination in Drosophila tracheal cells. J Cell Biol 2011, 124:240-251.

72. Aman A, Piotrowski T: Cell migration during morphogenesis. Dev Biol 2010, 341:20-33.

73. Pollack AL, Runyan RB, Mostov KE: Morphogenetic mechanisms of epithelial tubulogenesis: MDCK cell polarity is transiently rearranged without loss of cell-cell contact during scatter factor/hepatocyte growth factor-induced tubulogenesis. Dev Biol 1998, 204:64-79.

74. Schottenfeld J, Song Y, Ghabrial AS: Tube continued: morphogenesis of the Drosophila tracheal system. Current Opinion in Cell Biology 2010, 22:633-639.
75. Levi HW: Adaptations of respiratory systems of spiders. Evolution 1967 21:571-583.

76. Tsarouhas V, Senti K-A, Jayaram SA, Tiklová K, Hemphälä J, Adler J, Samakovlis C: Sequential pulses of apical epithelial secretion and endocytosis drive airway maturation in Drosophila. Development Cell 2007, 13:214-225.

77. Jayaram SA, Senti K-A, Tiklová K, Tsarouhas V, Hemphälä J, Samakovlis C COPI vesicle transport is a common requirement for tube expansion in Drosophila. PLoS ONE 2008, 3:1-11.

78. Förster D, Armbruster K, Luschnig S: Sec24-dependent secretion drives cell- autonomous expansion of tracheal tubes in Drosophila. Current Biology 2010, 20:62-68.

79. Norum M, Täng E, Chavoshi T, Schwarz H, Linke D, Uv A, Moussian B: Trafficking through COPII stabilises cell polarity and drives secretion during Drosophila epidermal differentiation. PLOS ONE 2010, 5:1-15.

80. Farley RD: Regulation of air and blood flow through the book lungs of the desert scorpion, Paruroctonus mesaensis. Tissue \& Cell 1990, 22:547-569.

81. Farley RD: Functional organization of the respiratory and circulatory systems in the desert scorpion Paruroctonus mesaensis. Acta Zoologica Fennica 1990, 190:139-145.

82. Willmer P: Invertebrate Relationships, Patterns in Animal Evolution Cambridge: Cambridge University Press; 1990, 1-400.

83. Polis GA, Sissom WD: Life history. In The Biology of Scorpions. Edited by: Polis GA. Stanford, CA: Stanford University Press; 1990:161-223.

84. Farley RD: Structure, reproduction and development. In Scorpion Biology and Research. Edited by: Brownell P, Polis G. Oxford/New York: Oxford University Press; 2001:13-78.

85. Coddington JA, Giribet G, Harvey MS, Prendini L, Walter DE: Arachnida. In Assembling the Tree of Life. Edited by: Cracraft J, Donoghue MJ. Oxford/New York: Oxford University Press; 2004:296-318.

86. Warburg MR: Reproductive system of female scorpion: a partial review. The Anatomical Record 2010, 293:1738-1754.

87. Kingsley JS: The embryology of Limulus. J Morph 1892, 7:35-68.

88. Ribeiro C, Neumann M, Affolter M: Genetic control of cell intercalation during tracheal morphogenesis in Drosophila. Current Biology 2004, 14:2197-2207.

89. Andrew DJ, Ewald AJ: Morphogenesis of epithelial tubes: insights into tube formation, elongation and elaboration. Dev Biol 2010, 341:34-55.

90. Behr M: Molecular aspects of respiratory and vascular tube development. Respiratory Physiology and Neurobiology 2010, 173S:S33-S36.

91. Swanson LE, Beitel GJ: Tubulogenesis: an inside job. Current Biology 2006 16:R51-53.

92. Shultz JW: Evolutionary morphology and phylogeny of Arachnida. Cladistics 1990, 6:1-38.

93. Shultz JW: A phylogenetic analysis of the arachnid orders based on morphological characters. Zool J Linn Soc 2007, 150:221-265.

94. Dunlop JA, Webster M: Fossil evidence, terrestrialization and arachnid phylogeny. J Arachnol 1999, 27:86-93.

doi:10.1186/1742-9994-8-18

Cite this article as: Farley: The ultrastructure of book lung development in the bark scorpion Centruroides gracilis (Scorpiones: Buthidae). Frontiers in Zoology 2011 8:18.

\section{Submit your next manuscript to BioMed Central and take full advantage of:}

- Convenient online submission

- Thorough peer review

- No space constraints or color figure charges

- Immediate publication on acceptance

- Inclusion in PubMed, CAS, Scopus and Google Scholar

- Research which is freely available for redistribution

Submit your manuscript at www.biomedcentral.com/submit
C Biomed Central 